\title{
28. PLIO-PLEISTOCENE BENTHIC FORAMINIFER STRATIGRAPHIC DISTRIBUTION IN THE DEEP-SEA RECORD OF THE TYRRHENIAN SEA (ODP LEG 107) ${ }^{1}$
}

\author{
R. Sprovieri ${ }^{2}$ and S. Hasegawa ${ }^{3}$
}

\begin{abstract}
Benthic foraminifers from Site 652, Site 653 (Hole 653A), and Site 654 of Leg 107 (Tyrrhenian Sea, Western Mediterranean), which penetrated with more or less good recovery the Plio-Pleistocene stratigraphic interval, were studied in a total of 699 close-spaced samples. A total number of 269 species have been classified and their quantitative distribution in each sample is reported. The benthic foraminifers assemblage is more diversified in Site 654, less diversified in Site 652. Less than a half of the benthic foraminifers species listed from Plio-Pleistocene Italian land sections are present in the coeval deep-sea Tyrrhenian record, in which shallow water species are missing and Nodosarids are poorly represented. A very few species have comparable stratigraphic distribution in the three deep-sea sequences and in Italian land sections when compared against calcareous plankton biostratigraphy. In the same three sites, the first appearance levels of several species are younger and younger, and last appearance levels are earlier and earlier from Site 654 to Site 653 and Site 652 . Five biostratigraphic events, biochronologically evaluated and occurring at the same level in the deepsea Tyrrhenian record and in several land sections, have been selected as zonal boundaries of the proposed benthic foraminifers biostratigraphic scheme. The Plio-Pleistocene interval has been subdivided into four biozones and one subzone, recognizable both in the deep-sea and land-based sequences. The Cibicidoides(?) italicus assemblage zone stretches from the base of the Pliocene to the extinction level of the zonal marker, biochronologically evaluated at $2.9 \mathrm{Ma}$. The Cibicidoides robertsonianus interval zone stretches from the Cibicidoides(?) italicus extinction level to the Pliocene Mediterranean FO of Gyroidinoides altiformis, evaluated at 2.4 Ma. The Gyroidinoides altiformis interval zone stretches from the Mediterranean Pliocene FO of the zonal marker to the appearance level of Articulina tubulosa, evaluated at $1.62 \mathrm{Ma}$. The Articulina tubulosa assemblage zone stretches from the appearance level of the zonal marker to the Recent. In the Articulina tubulosa biozone, the Hyalinea baltica subzone is proposed. The appearance level of Hyalinea baltica is evaluated at $1.35 \mathrm{Ma}$, well above the Plio-Pleistocene boundary as defined in the Vrica stratotype section.
\end{abstract}

\section{INTRODUCTION}

Mediterranean Plio-Pleistocene benthic foraminifers have been studied by several authors since the last century. Their studies were initially devoted primarily to species recognition and classification (De Amicis, 1895; Fornasini, 1894; Seguenza, 1880; A. Silvestri, 1899; 1904; and O. Silvestri, 1872). With the beginning of systematic oil exploration by the Italian oil company (AGIP) in the 1950's, benthic foraminifers were used as the main biostratigraphic tool, as the great biostratigraphic value of planktonic foraminifers was yet not recognized. Much of our understanding of the biostratigraphic value of Tertiary and Quaternary benthic foraminifers comes from AGIP publications $(1957,1982)$. In this same period of time many papers, including more or less detailed analyses on the stratigraphic distribution of the Italian Plio-Pleistocene benthic foraminifers, were published by several authors. Only a few of the more than 600 species recognized in the Mediterranean Pliocene and Pleistocene stratigraphic record can be considered as useful biostratigraphic markers in the Mediterranean basin and some of them have been already used to identify benthic foraminifers zonal boundaries (Colalongo and Sartoni, 1979; AGIP, 1982; Colalongo et al., 1982; d'Onofrio, 1983). Furthermore, two stratigraphic intervals characterized by the disappearance, or definite migration from the Mediterranean, of several benthic species have been recently identified (van der Zwaan, 1983; Sprovieri, 1985). These two extinction events, well recognizable in sequences

\footnotetext{
${ }^{1}$ Kastens, K. A., Mascle, J., et al., 1990 Proc. ODP, Sci. Results, 107: College Station, TX (Ocean Drilling Program).

2 Department of Geology and Geodesy, Corso Tukory 131, Palermo, Italy

${ }^{3}$ Institute of Geology and Paleontology, Faculty of Science, Tohoku University, Aobayama, Sendai 980, Japan.
}

belonging to epibathyal and lower neritic environment (Sprovieri, 1985), are easily correlatable with paleoceanographic and paleoclimatic changes and are useful references for correlation within the Mediterranean basin (Rio et al., 1984; Rio and Sprovieri, 1986).

Most of the data on the distribution of the Mediterranean Plio-Pleistocene benthic foraminifers come from land sections or wells drilled for oil researches. During the ODP Leg 107 cruise in the Tyrrhenian basin, three sites $(654,653,652)$ have been continuously cored with good to very good recovery in the Plio-Pleistocene sequence. They represent a good opportunity to compare and extend the analysis on the stratigraphic distribution of the benthic foraminifers of this time interval to the deepsea benthic foraminifers assemblage. Such a stratigraphic study was not reported from the two previous DSDP cruises in the Mediterranean (Leg 13 and Leg 42A), during which complete and continuous Plio-Pleistocene sequences were not cored (apart from Site 132), and the primary focuses were on paleoecological considerations (Ryan et al., 1973; Wright 1978a, b).

This paper is therefore essentially devoted to the analysis of the stratigraphic distribution of the benthic foraminifers in the Tyrrhenian sites and to the identification of a stratigraphic scheme, possibly recognizable also in the Italian land sections. In this respect, biostratigraphic data on benthic foraminifers stratigraphic distribution from land sections are considered. $\mathrm{Pa}$ leoecological analysis of the benthic foraminifers assemblage and paleoenvironmental evolution in the three sites are discussed in the paper by Hasegawa, Sprovieri, and Poluzzi (this volume).

\section{MATERIALS AND METHODS}

The benthic foraminifers assemblages from the Plio-Pleistocene sequences recovered in Site 654, Hole 653A, and Site 652, drilled in the Tyrrhenian Sea during Leg 107 (Fig. 1) were studied. Site 654 was drilled in the upper part of the Sardinian conti- 


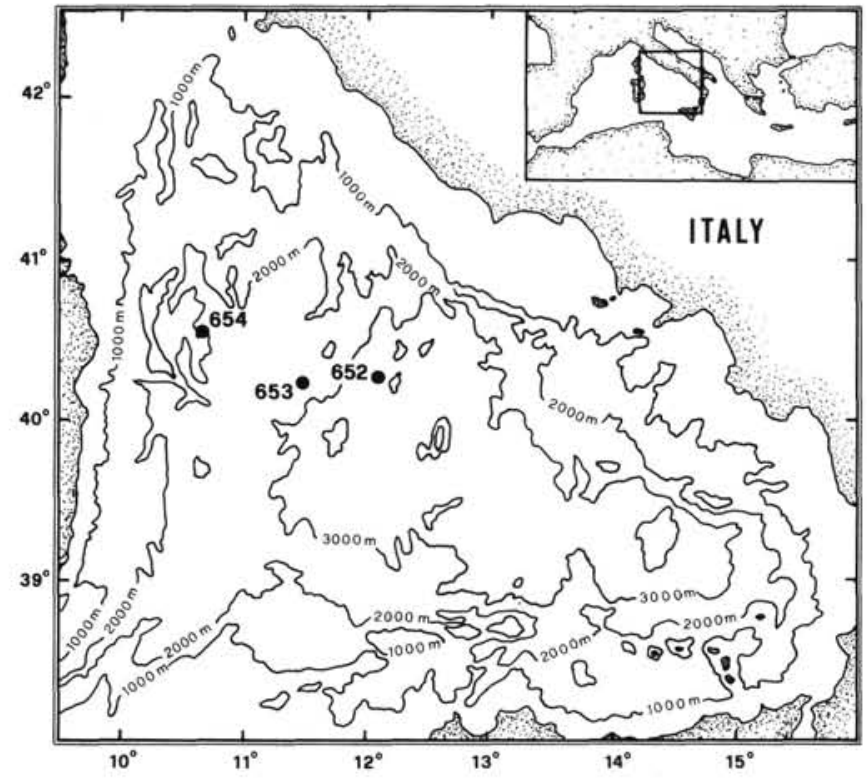

Figure 1. Location map of the ODP Leg 107 Site 654, Site 653, and Site 652

nental margin, at $2208 \mathrm{~m}$ depth $\left(40^{\circ} 34.76^{\prime} \mathrm{N} ; 10^{\circ} 41.80^{\prime} \mathrm{E}\right)$. The Plio-Pleistocene sequence is $242.7 \mathrm{~m}$ thick. Recovery was not very good (about $50 \%$ ), with several more or less long unrecovered intervals. Site 653 is located one-half kilometer northeast of DSDP Site 132 (Leg 13), on the eastern rim of the Cornaglia basin, at $2817 \mathrm{~m}$ depth $\left(40^{\circ} 15.86^{\prime} \mathrm{N}, 11^{\circ} 26.99^{\prime} \mathrm{E}\right)$. The PlioPleistocene sequence is $214 \mathrm{~m}$ thick. The recovery was very good $(81.9 \%)$, with only few, short unrecovered intervals. Site 652 is located in the lower part of the Sardinian continental margin, at $3446 \mathrm{~m}$ depth $\left(40^{\circ} 21.30^{\prime} \mathrm{N} ; 1^{\circ} 08.59^{\prime} \mathrm{E}\right)$. The Plio-Pleistocene sequence is $188 \mathrm{~m}$ thick. Recovery was not very good $(61.2 \%)$, with several more or less long unrecovered intervals. Sequences from other Leg 107 Sites were not considered since they penetrated only the Pleistocene and a part of the Pliocene and contained numerous unrecovered segments. As reported in Tables 2-4 (microfiche in pocket), in Site 652 and Site 654 the sampled levels, if present, are from about 15,75 , and $115 \mathrm{~cm}$ of each section; in Hole 653A the sampled levels are from about 15, 45, 75, and $105 \mathrm{~cm}$. Essentially levels from 75 and 115 (or 105) $\mathrm{cm}$ of each section were studied. Levels at 15 and $45 \mathrm{~cm}$ were analyzed quite systematically in Hole $653 \mathrm{~A}$; in the other sites, the level at $15 \mathrm{~cm}$ was analyzed only to better approximate the First Occurrence (FO) or Last Occurrence (LO) of selected species. From levels at 15, 45, 75, and $105 \mathrm{~cm}$ of each section of Site 653, 10 $\mathrm{cm}^{3}$ of sediments were available; from level at $115 \mathrm{~cm}$ of each section of Site 652 and Site $654,20 \mathrm{~cm}^{3}$ were used.

All the samples, after disaggregation in water, were washed on a $63-\mu \mathrm{m}$ sieve. All benthic foraminifers $>125 \mu \mathrm{m}$ were identified and counted. Specimens $<125 \mu \mathrm{m}$ were classified but not counted. The symbol 0 (for presence) was used in the quantitative range tables (Tables 2-4) for the species recognized in this part of the residue. The number of specimens of each species takes into consideration only the specimens recorded in the residue $>125 \mu \mathrm{m}$.

\section{DATA ANALYSIS AND DISCUSSION}

In the three sites benthic foraminifers always represent a very small percentage of the faunistic assemblage, generally less than $2 \%-3 \%$. The most abundant and diversified benthic foraminiferal assemblage is present in Site 654 , the least abundant in Site
652. Specimens are well preserved and dissolution was not observed. Very rare specimens of displaced neritic species ( $\mathrm{Ammo-}$ nia spp., Elphidium spp, Discorbis spp.) were recognized at only a few levels. Specimens of Cibicides lobatulus, Cibicides refulgens, Hanzawaia rodhiensis, and Rosalina cf. nitida, sometime present with several specimens in many samples, are not considered indicative of synsedimentary displacement. These species, essentially with an epiphytic mode of life, can be included in bathyal assemblages as consequence of flotation of the algal support once it is removed from its original place by storms.

All in all, 699 samples were studied and 269 species were recognized, the most significant of which are figured in Plates 1-5. In Table 1 the main data of each stratigraphic interval are reported. The distribution of each species, the number of specimens per sample of each species, and the total number of species per sample in each site are reported in Tables 2-4. In Figures 2,7 , and 12 , the number of species, the number of specimens, and the diversity index per sample along the three sequences are plotted. The diversity index was calculated (Margalef, 1958; Parisi et al., 1982) as

$$
\mathrm{D}=\mathrm{n} \text { species }-1 / \log \mathrm{n} \text { specimens. }
$$

Less than half of the benthic foraminifers species recorded from Plio-Pleistocene Italian land sections were recognized in the coeval deep-sea sequences of the three Tyrrhenian sites. Two groups are essentially missing. The first one includes the shallow water, neritic species which, while they comprise large constituents of the benthic foraminiferal assemblage in some Italian land sections, are environmentally excluded from these deep-sea bathyal sediments. The second group is represented by Nodosarids which, while very well diversified in the Pliocene land section interval, are represented here by rare and scattered occurrences.

In this section the general trend of the faunistic assemblage is briefly reported, and the stratigraphic distribution of some species is discussed at the light of the calcareous plankton biostratigraphy and in the rigid time framework provided by the integrated calcareous plankton stratigraphy recognized in the three sites (Glaçon, Rio, and Sprovieri, this volume; Rio, Raffi, and Villa, this volume). These species were selected on the base of their abundance along the sequences and/or on the base of their potential biostratigraphic interest for the Mediterranean Plio-Pleistocene stratigraphic record, also with reference to the data from the Italian land sections. The stratigraphic distribution of the most important of them in the three sites is reported in Figures 3,8 , and 13 , in which the appearance and disappearance levels are traced in coincidence with the first or last sample in which the species is recorded. Their frequency distribution (percentage) is plotted in Figures 4-6, 9-11, and 14-16, in which only data from samples with at least six specimens are reported. Only a small number of species is common and continuously present in the samples within their stratigraphic range. Furthermore, their first and last occurrence is rarely comparable among the sites and with the same events recognized in land sections. Generally their disappearance levels predate, and the appearance level postdates, the corresponding events identified in land sections. Even in the three sites the FO or LO of very few species occur at the same stratigraphic level. The disappearance levels of several species are earlier and earlier and the appearance levels are younger and younger from Site 654 to Site 653 and Site 652 (Figs. 3, 8, and 13). The disappearance level of some species, such as Parrelloides bradyi and Quinqueloculina bicarinata and the appearance level of Gyroidinoides altiformis, Articulina tubulosa, and Cibicidoides kullenbergi seem to have different, even opposite trends when biostratigraphically and biochronologically evaluated. Nevertheless, in the identification of these 
Table 1. Main data of the stratigraphic intervals analyzed in the three sites.

\begin{tabular}{|c|c|c|c|}
\hline & Site 654 & Site 653 & Site 652 \\
\hline \multicolumn{4}{|l|}{ General } \\
\hline Depth interval & $0-243$ & $0-215$ & $1-188$ \\
\hline Thickness (m) & 243 & 215 & 188 \\
\hline Number of studied samples & 168 & 344 & 187 \\
\hline Total number of species & 232 & 205 & 163 \\
\hline Max. number of species per sample & 70 & 37 & 33 \\
\hline Min. number of species per sample & 1 & 1 & 1 \\
\hline \multicolumn{4}{|l|}{ MPII } \\
\hline Depth interval & $236.40-243$ & $208.96-215$ & $176.25-188$ \\
\hline Thickness (m) & 6.60 & 6.04 & 11.75 \\
\hline Number of studied samples & 6 & 11 & 20 \\
\hline Total number of species & 67 & 32 & 36 \\
\hline Max. number of species per sample & 36 & 23 & 17 \\
\hline Min. number of species per sample & 23 & 4 & 1 \\
\hline \multicolumn{4}{|l|}{ MPI2 } \\
\hline Depth interval & $197.50-236.40$ & $186.35-208.96$ & $146.80-176.25$ \\
\hline Thickness (m) & 38.90 & 22.61 & 29.45 \\
\hline Number of studied samples & 39 & 38 & 41 \\
\hline Total number of species & 139 & 87 & 76 \\
\hline Max. number of species per sample & 64 & 31 & 29 \\
\hline Min. number of species per sample & 22 & 1 & 2 \\
\hline \multicolumn{4}{|l|}{ MP13 } \\
\hline Depth interval & $166.50-157.50$ & $153.26-186.35$ & $126.47-146.80$ \\
\hline Thickness (m) & 31.00 & 33.09 & 20.33 \\
\hline Number of studied samples & 25 & so & 20 \\
\hline Total number of species & 139 & 87 & 52 \\
\hline Max. number of species per sample & 65 & 31 & 28 \\
\hline Min. number of species per sample & 26 & 5 & 8 \\
\hline \multicolumn{4}{|l|}{ MPI4 } \\
\hline Depth interval & $140.93-166.50$ & $133.00-153.26$ & $109.70-126.47$ \\
\hline Thickness (m) & 25.57 & 20.26 & 16.77 \\
\hline Number of studied samples & 26 & 33 & 18 \\
\hline Total number of species & 144 & 84 & 66 \\
\hline Max. number of species per sample & 70 & 33 & 27 \\
\hline Min. number of species per sample & 22 & 2 & 6 \\
\hline \multicolumn{4}{|l|}{ MPI5 } \\
\hline Depth interval & $105.00-140.60$ & $98.40-133.00$ & $100.33-109.70$ \\
\hline Thickness (m) & 35.60 & 34.60 & 9.37 \\
\hline Number of studied samples & 27 & 52 & 13 \\
\hline Total number of species & 138 & 115 & 55 \\
\hline Max. number of species per sample & 58 & 37 & 21 \\
\hline Min. number of species per sample & 23 & 7 & 5 \\
\hline \multicolumn{4}{|l|}{ MP16 } \\
\hline Depth interval & $79.70-105.00$ & $84.50-98.40$ & $84.90-100.33$ \\
\hline Thickness (m) & 25.30 & 13.90 & 15,43 \\
\hline Number of studied samples & 10 & 30 & 25 \\
\hline Total number of species & 106 & 70 & 61 \\
\hline Max. number of species per sample & 49 & 28 & 33 \\
\hline Min. number of species per sample & 21 & 3 & 4 \\
\hline \multicolumn{4}{|l|}{ Pleistocene } \\
\hline Depth interval & $0-79.70$ & $0-84.50$ & $0-84.90$ \\
\hline Thickness (m) & 79.70 & 84.50 & 84.90 \\
\hline Number of studied samples & 35 & 130 & 50 \\
\hline Total number of species & 129 & 151 & 102 \\
\hline Max. number of species per sample & 45 & 28 & 31 \\
\hline Min. number of species per sample & 7 & 1 & 1 \\
\hline
\end{tabular}

LO's and FO's, sedimentary hiatuses (Glaçon, Rio, and Sprovieri, this volume) and poor recovery in the pertinent stratigraphic intervals must be considered.

The general benthic foraminiferal assemblage distribution is quite well comparable among the three sites (Tables 2-4). Nodosarids are generally rare and scattered; Cibicidids and Gyroidinoides spp. are more common in the Pliocene intervals and decrease in the Pleistocene; Bolivinids, Buliminids, and Cassidulinids are more common in the Pleistocene interval; Uvigerinids are rare, essentially present in a short interval at the base of the
Pliocene (MP11-base MP12 biozones); Miliolids are well represented essentially in the latest Pliocene and in the Pleistocene intervals; Fissurina spp., Lagena spp., and Oolina spp. are represented by many species all along the sequences but with very rare specimens; agglutinated forms, essentially represented by Bigenerina nodosaria, Karreriella spp., and Martinottiella spp., are generally common but decrease in the late Pleistocene.

The Sphaeroidinellopsis spp. (MP11) biozone is characterized by a greater number of species in Site 654 (in which only the uppermost part of this biozone is present), but the same few species Dentalina filiformis, Gyroidinoides soldanii, Globocassidulina subglobosa, Oridorsalis stellatus, and, in the upper part, Uvigerina pygmaea are common in the three sites. An increase in the number of species occurs in the Globorotalia margaritae (MPl2) biozone. The benthic assemblage is dominated by $\mathrm{Si}$ phonina reticulata, Cibicidoides(?) italicus, Oridorsalis stellatus, Parrelloides bradyi, P. robertsonianus, and Pullenia spp.; in Site 654 Planulina ariminensis and Sphaeroidina bulloides are common. In the basal part of this interval Uvigerina pygmaea is relatively common for a short interval. In the three Tyrrhenian sites in the interval straddling the MP11-MP12 zonal boundary, brilliant, yellow to reddish sediments contain hematite, limonite, sulfur, and sulfates. A large amount of nutrients were also probably carried from weathered exposed sediments into the basin together with these iron oxides, favoring the dominance of Uvigerina pygmaea; according to many authors (Phleger and Soutar, 1973; Boltovskoy and Wright, 1976; Brolsma, 1978; Streeter and Shackleton, 1979; Douglas and Woodruff, 1981; van der Zwaan, 1982; Katz and Thunell, 1984), Uvigerina is considered to be very tolerant of low oxygen levels. Vaginulina elegans and Vaginulinopsis carinata are present, with one specimen, only in one sample of this interval in Site 654. They belong to a group of several species, many of which belonging to Vaginulina and Vaginulinopsis, which disappear, according to data from land sections (Sprovieri, 1978; AGIP, 1982; Sprovieri, 1985), in the middle-upper part of the Sphaeroidinellopsis subdehiscens (MP14) biozone. Ellipsoglandulina vasarhelyi, which disappears in the MP14 biozone in land sections, is present, rare, only in a few samples of this interval in Site 654 .

The benthic foraminiferal assemblage of the Globorotalia margaritae-Globorotalia puncticulata zone (MP13) is well comparable with the MPI2 zone assemblage. The highest stratigraphic occurrence of Uvigerina rutila, a widely used biostratigraphic marker of the lower part of the Mediterranean Pliocene in the Italian land sections, is recorded in the upper part of this interval in Site 654. In land sections this species ranges up to the upper part of the Sphaeroidinellopsis subdehiscens zone (Sprovieri, 1978; Colalongo and Sartoni, 1979; Colalongo et al., 1982; AGIP, 1982; Sprovieri, 1985). In Hole 653A Anomalinoides helinus disappears in the middle part of MP13 biozone (Sample $17 \mathrm{X}-6,15 \mathrm{~cm} ; 153.26 \mathrm{mbsf}) ;$ in Site 654 and in the Italian land sections this species ranges up to the upper part of the Globigerinoides elongatus (MP15) biozone (Sprovieri, 1978; Colalongo and Sartoni, 1979; Colalongo et al., 1982; AGIP, 1982; van der Zwaan, 1983; Sprovieri, 1985). In the middle-lower part of MP13 biozone Cylindroclavulina rudis appears with rare specimens and ranges up to the very base of MPl5 in Site 654. This species is generally well represented in this interval in the Italian land sections (Sprovieri, 1977, 1978, 1979; AGIP, 1982), where it disappears in the upper part of the Pliocene. In the Sphaeroidinellopsis subdehiscens (MP14) biozone, the extinction level event at about 3.2-3.1 Ma (the mid-Pliocene event, according to Rio et al., 1984), easily recognizable in land sections (Sprovieri, 1985 ) is not detected in the three deep-sea Tyrrhenian sequences. It is well marked by the disappearance of several species of Lenticulina, Marginulina, Planularia, Vaginulina, and Vaginulinopsis, but these benthic foraminifers are poorly represented in the 


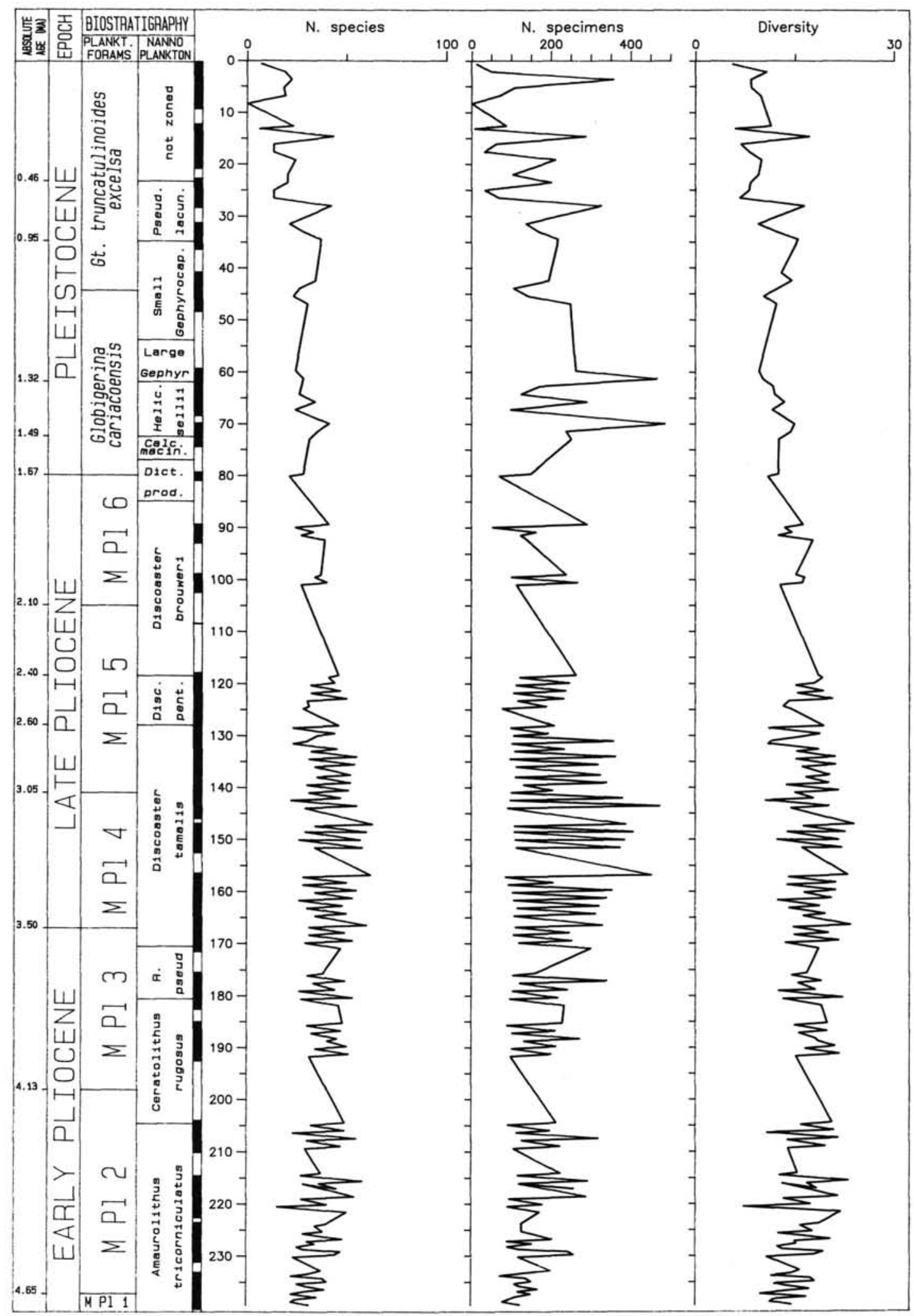

Figure 2. Plot of number of species, number of specimens, and diversity index of the benthic foraminifera in the PlioPleistocene sequence of Site 654 . Black vertical bars $=$ recovered intervals. 


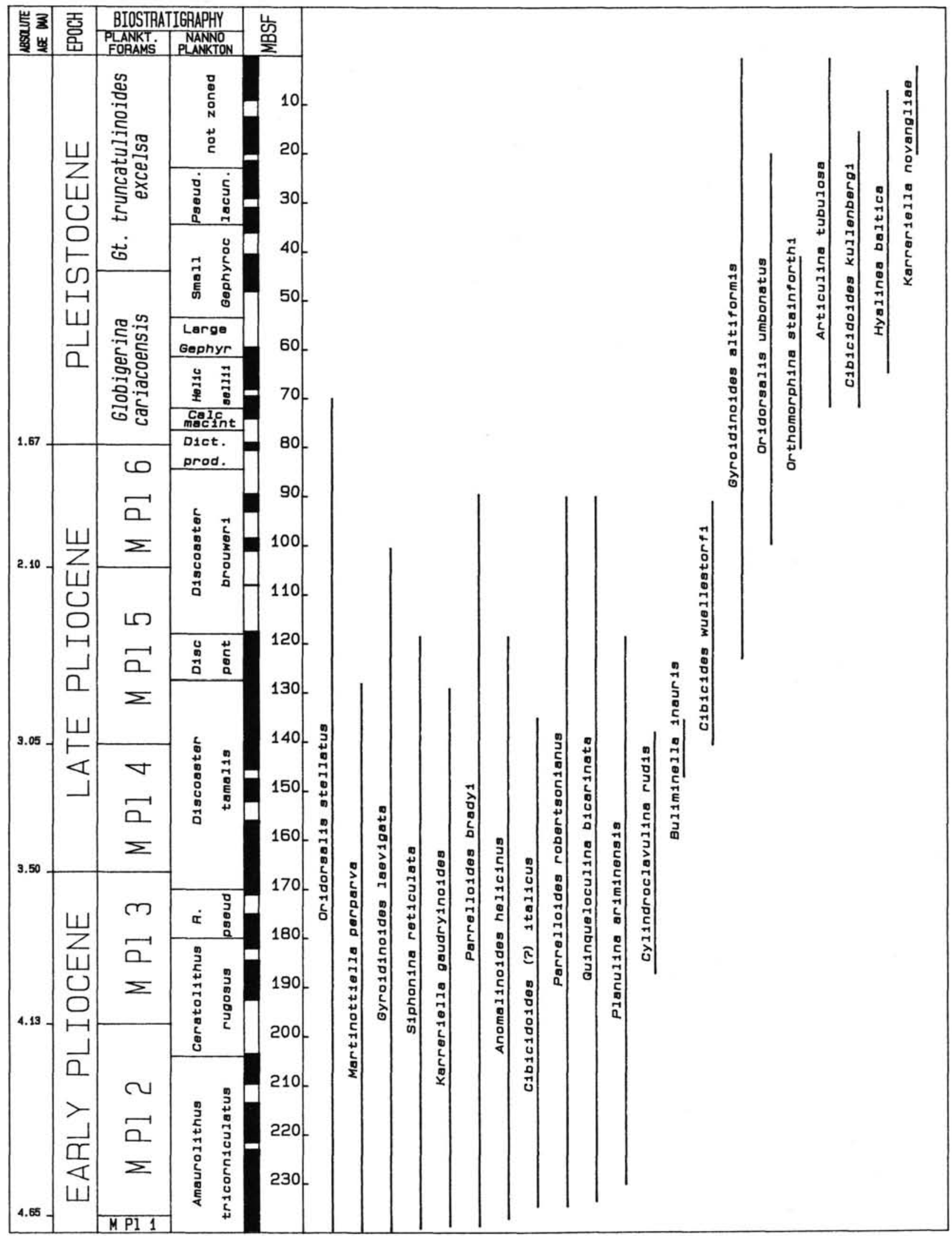

Figure 3. Stratigraphic distribution chart of the biostratigraphically most important benthic foraminifers in the Plio-Pleistocene sequence of Site 654. Black vertical bars $=$ recovered intervals. 


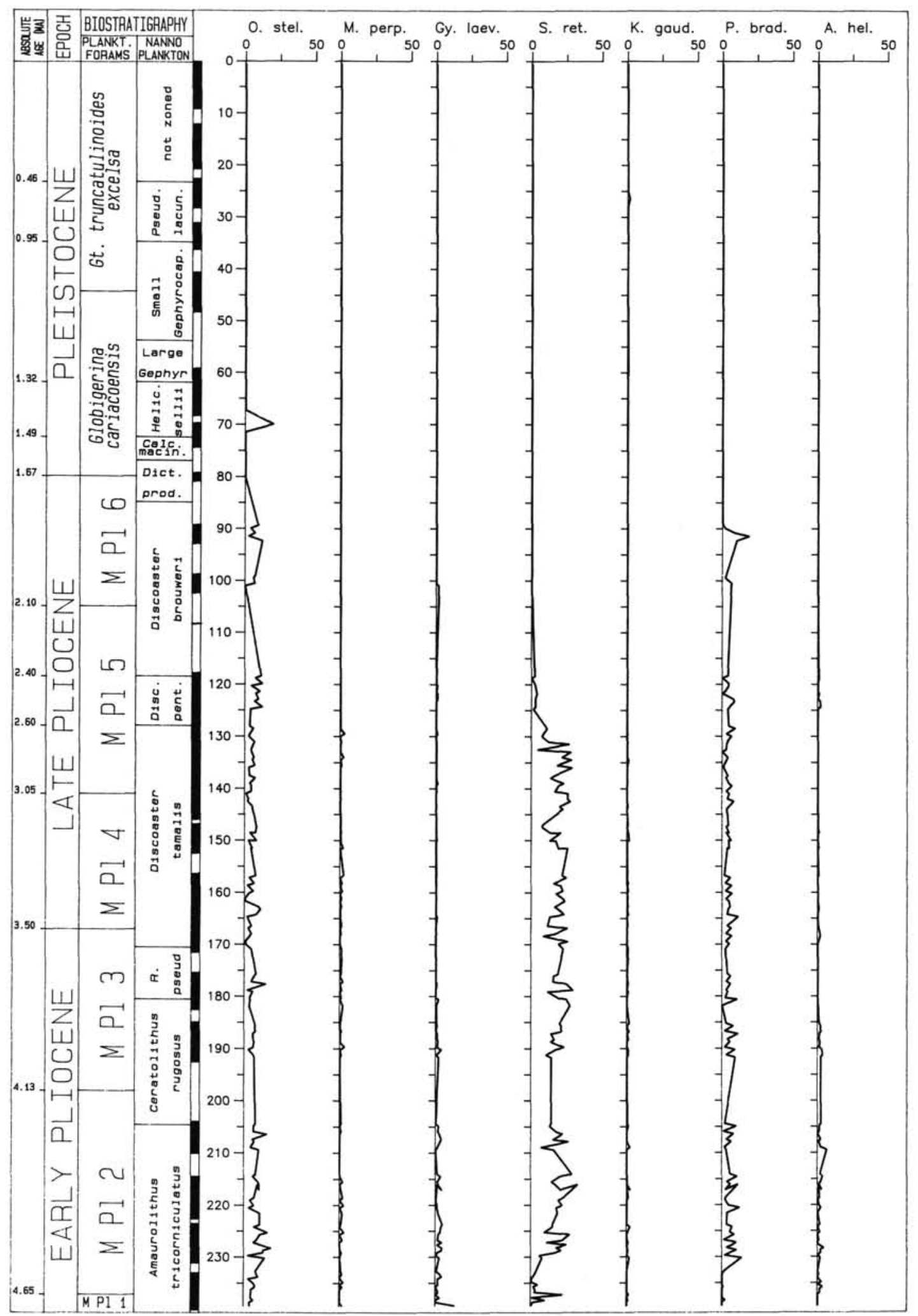

Figure 4. Frequency distribution (percentage) chart of benthic foraminifers species reported in Figure 3. O. stel. = Oridorsalis stellatus; M. perp. = Martinottiella perparva; Gy. laev. = Gyroidinoides laevigata; $\mathrm{S}$. ret. = Siphonina reticulata; $\mathrm{K}$. gaud. $=$ Karreriella gaudryinoides; P. brad. = Parrelloides bradyi; A. hel. = Anomalinoides helicinus. Black vertical bars $=$ recovered intervals. 


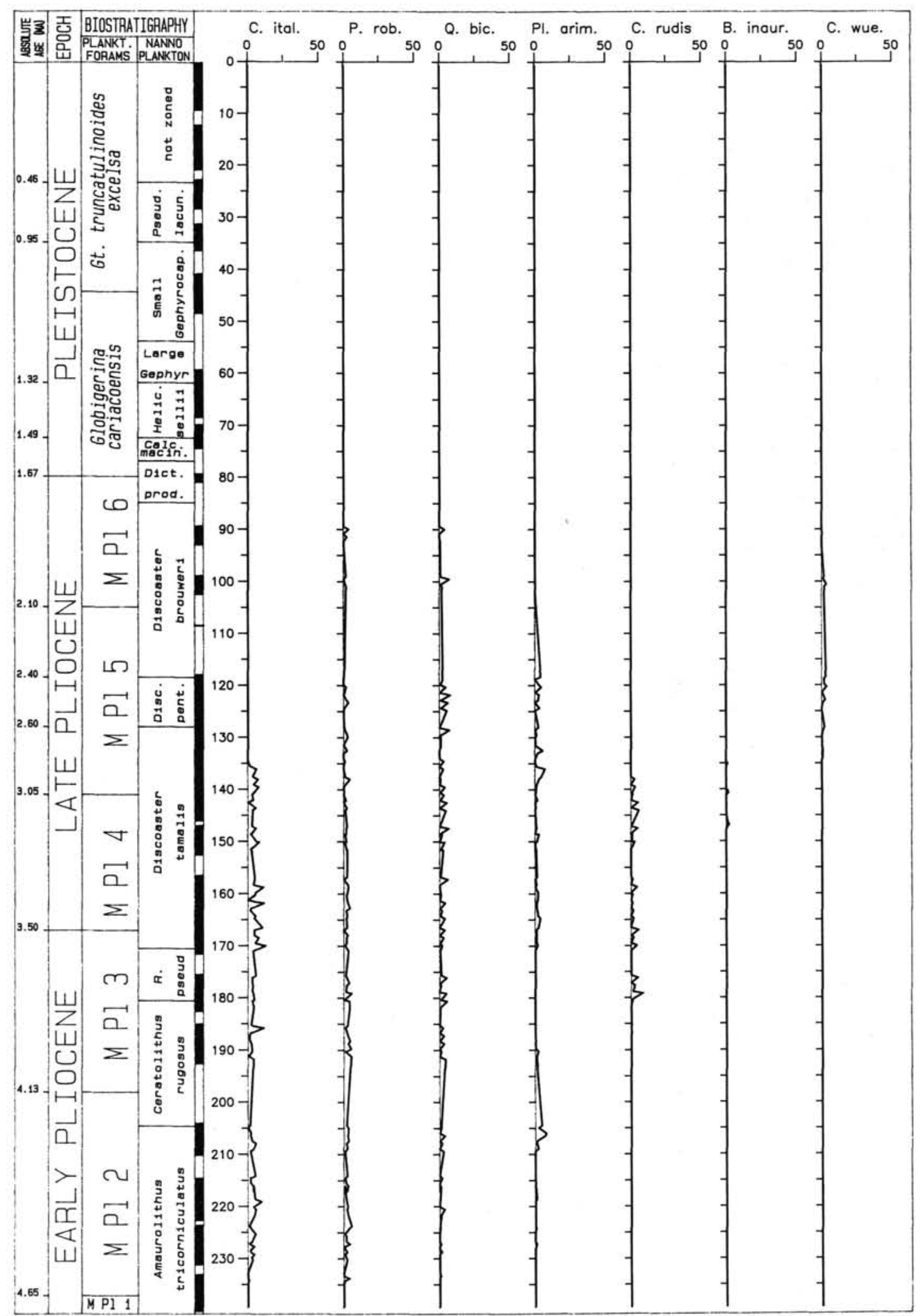

Figure 5. Frequency distribution (percentage) chart of benthic foraminifers species reported in Figure 3. C. ital. = Cibicidoides(?) italicus; P. rob. = Parrelloides robertsonianus; Q. bic. = Quinqueloculina bicarinata; Pl. arim. = Planulina ariminensis; C. rudis = Cylindroclavulina rudis; B. inaur. = Buliminella inauris; . . wue. = Cibicides wuellestorfi. Black vertical bars $=$ recovered intervals. 


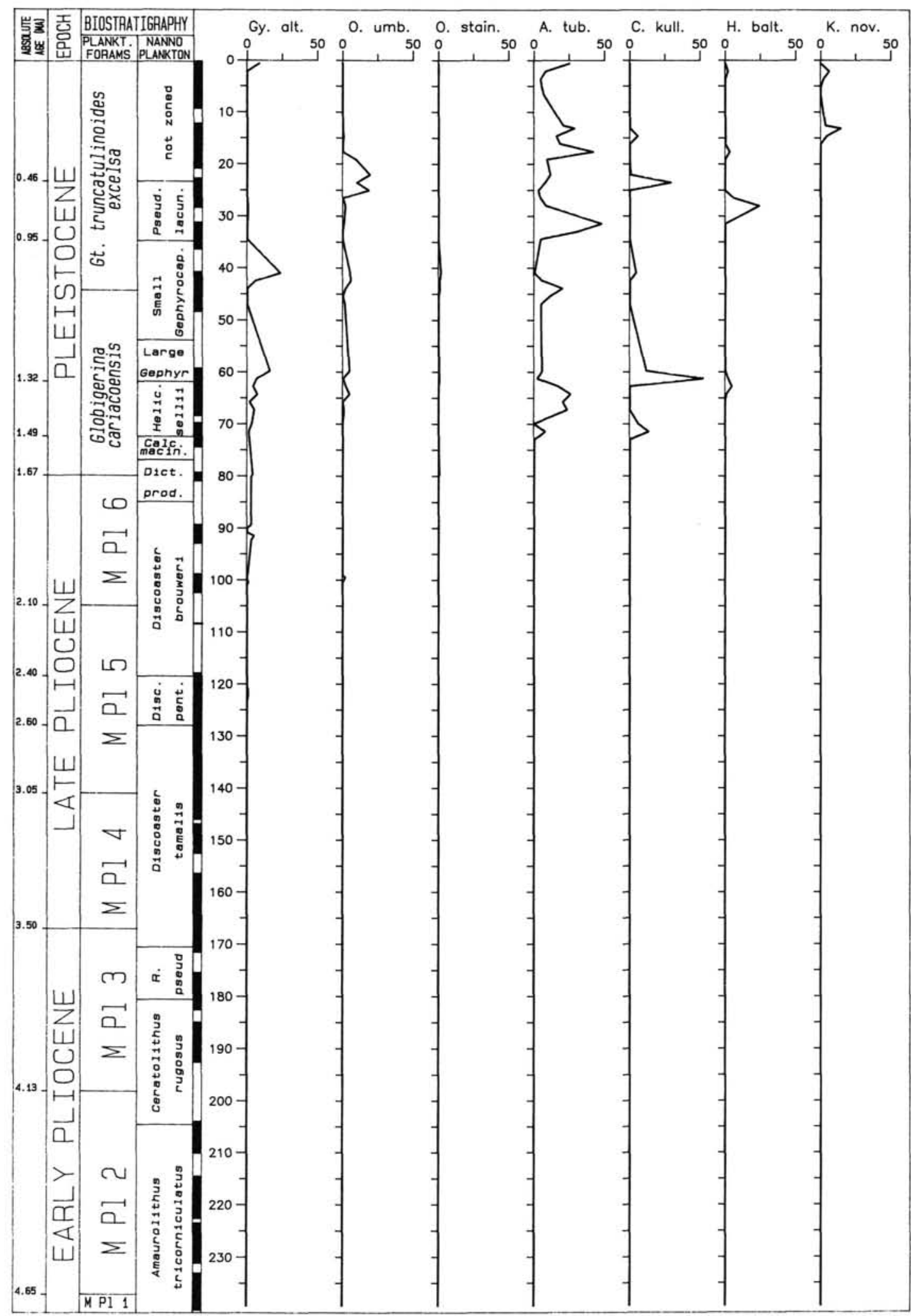

Figure 6. Frequency distribution (percentage) chart of benthic foraminifers species reported in Figure 3. Gy. alt. = Gyroidinoides altiformis; O. umb. = Oridorsalis umbonatus; O. stain. =Orthomorphina stainforthi; A. tub. = Articulina tubulosa; C. kull. = Cibicidoides $k$ kullenbergi; $\mathrm{H}$. bal. = Hyalinea baltica; K. nov. = Karreriella novangliae. Black vertical bars $=$ recovered intervals. 


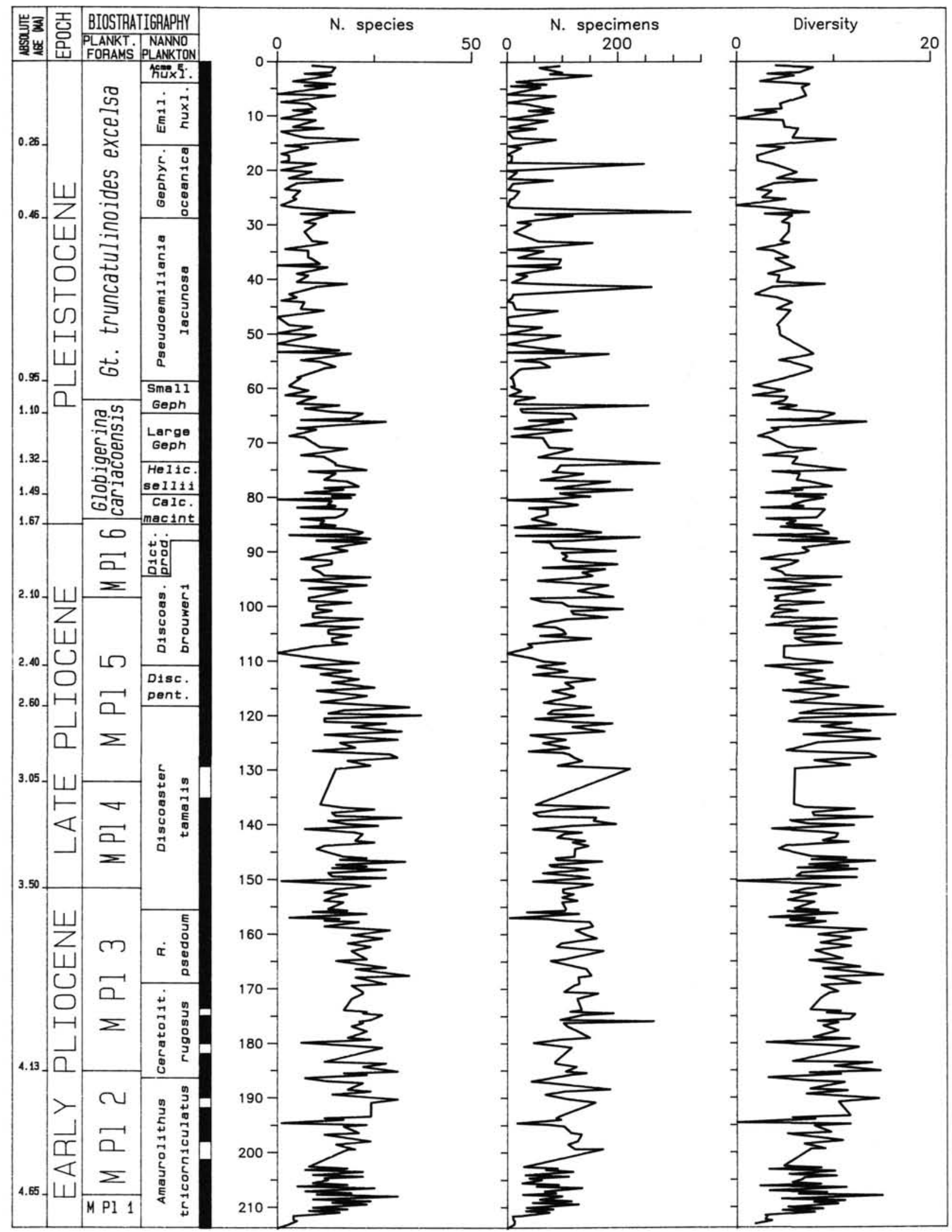

Figure 7. Plot of number of species, number of specimens, and diversity index of the benthic foraminifers in the Plio-Pleistocene sequence of Hole 653A. Black vertical bars $=$ recovered intervals. 


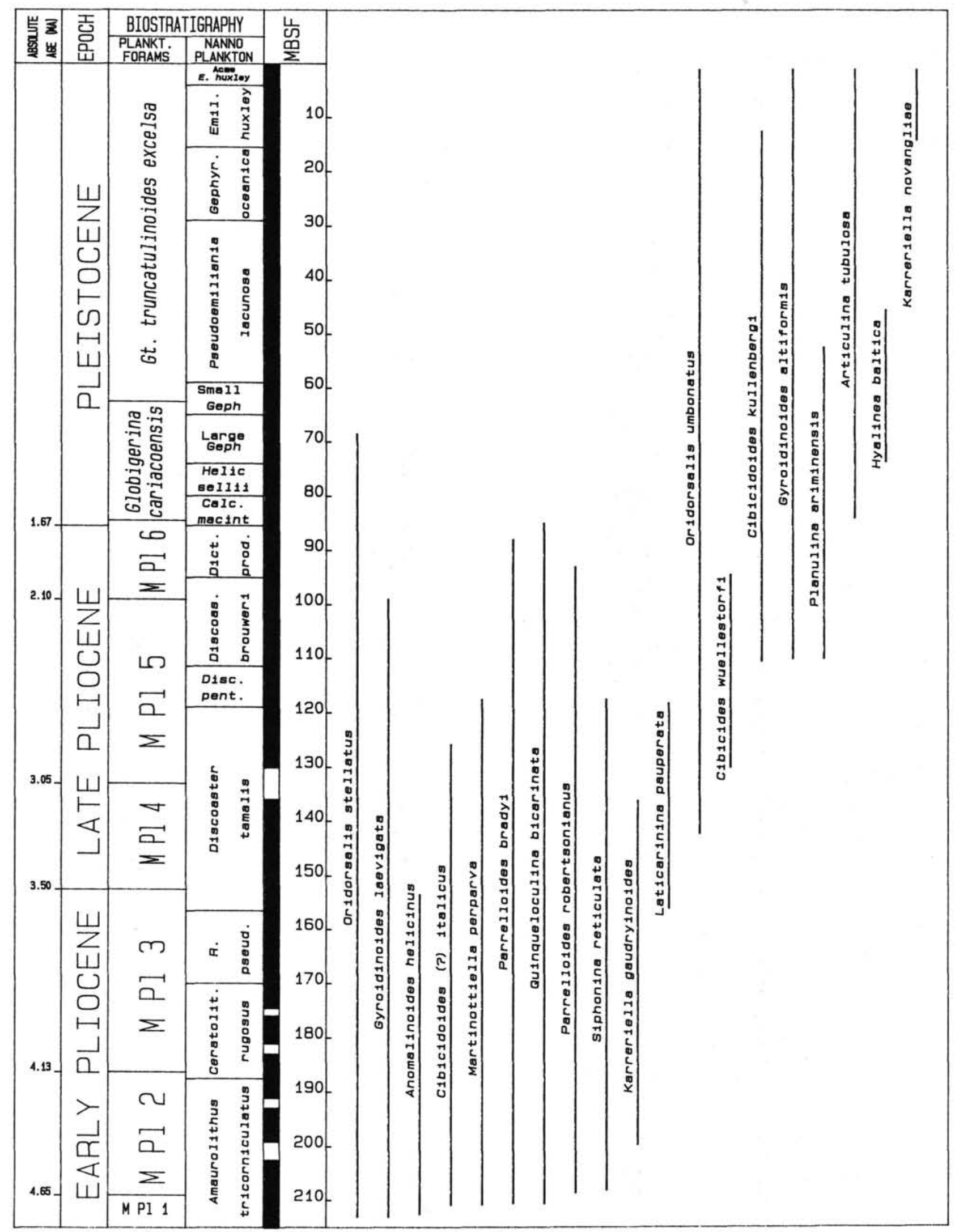

Figure 8. Stratigraphic distribution chart of the biostratigraphically most important benthic foraminifers in the Plio-Pleistocene sequence of Hole $653 \mathrm{~A}$. Black vertical bars $=$ recovered intervals. 


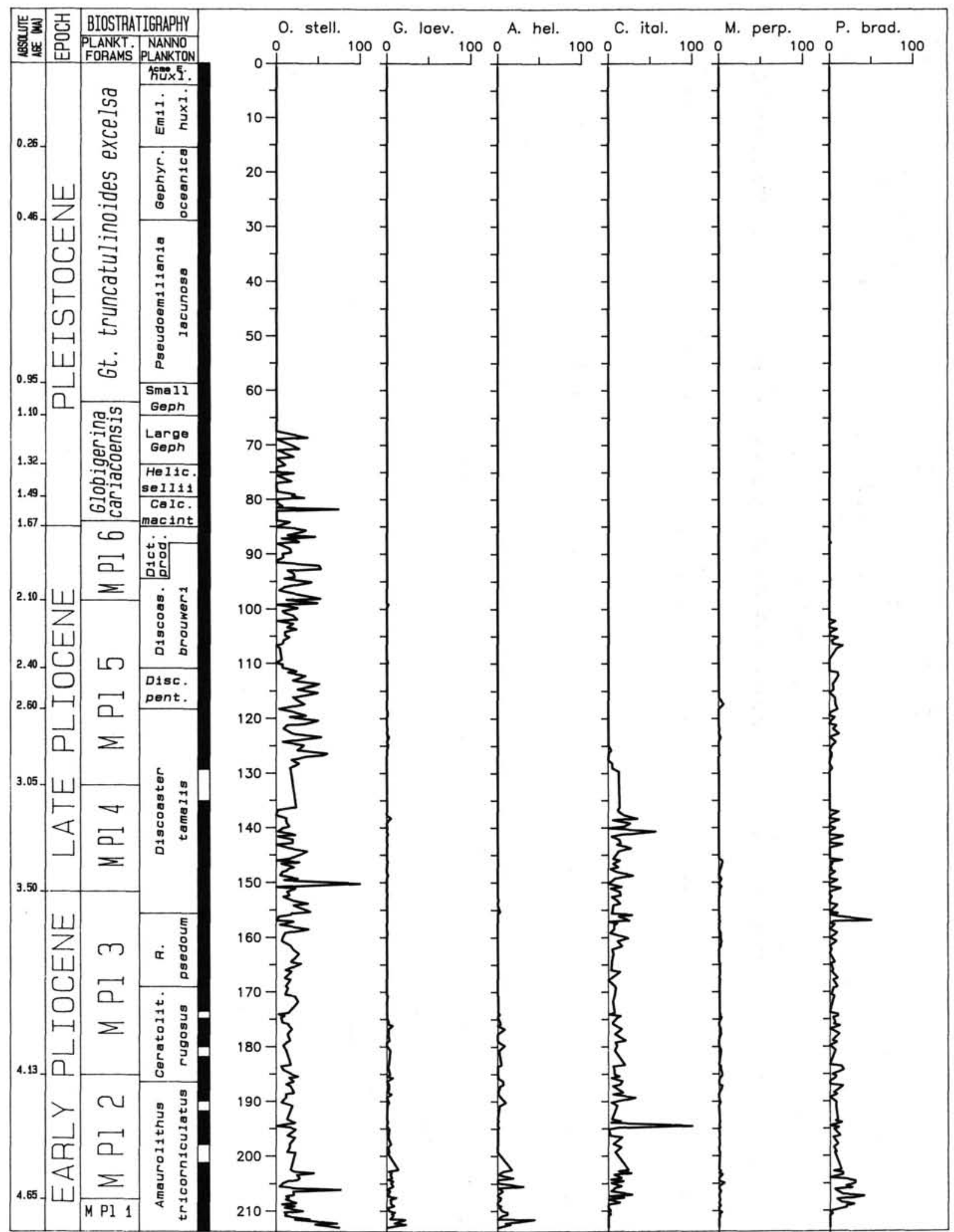

Figure 9. Frequency distribution (percentage) chart of benthic foraminifers species reported in Figure 8. O. stell. = Oridorsalis stellatus; G. laev. = Gyroidinoides laevigata; A. hel. = Anomalinoides helicinus; C. ital. = Cibicidoides(?) italicus; M. perp. = Martinottiella perparva; $\mathrm{P}$. brad. $=$ Parrelloides bradyi . Black vertical bars $=$ recovered intervals. 


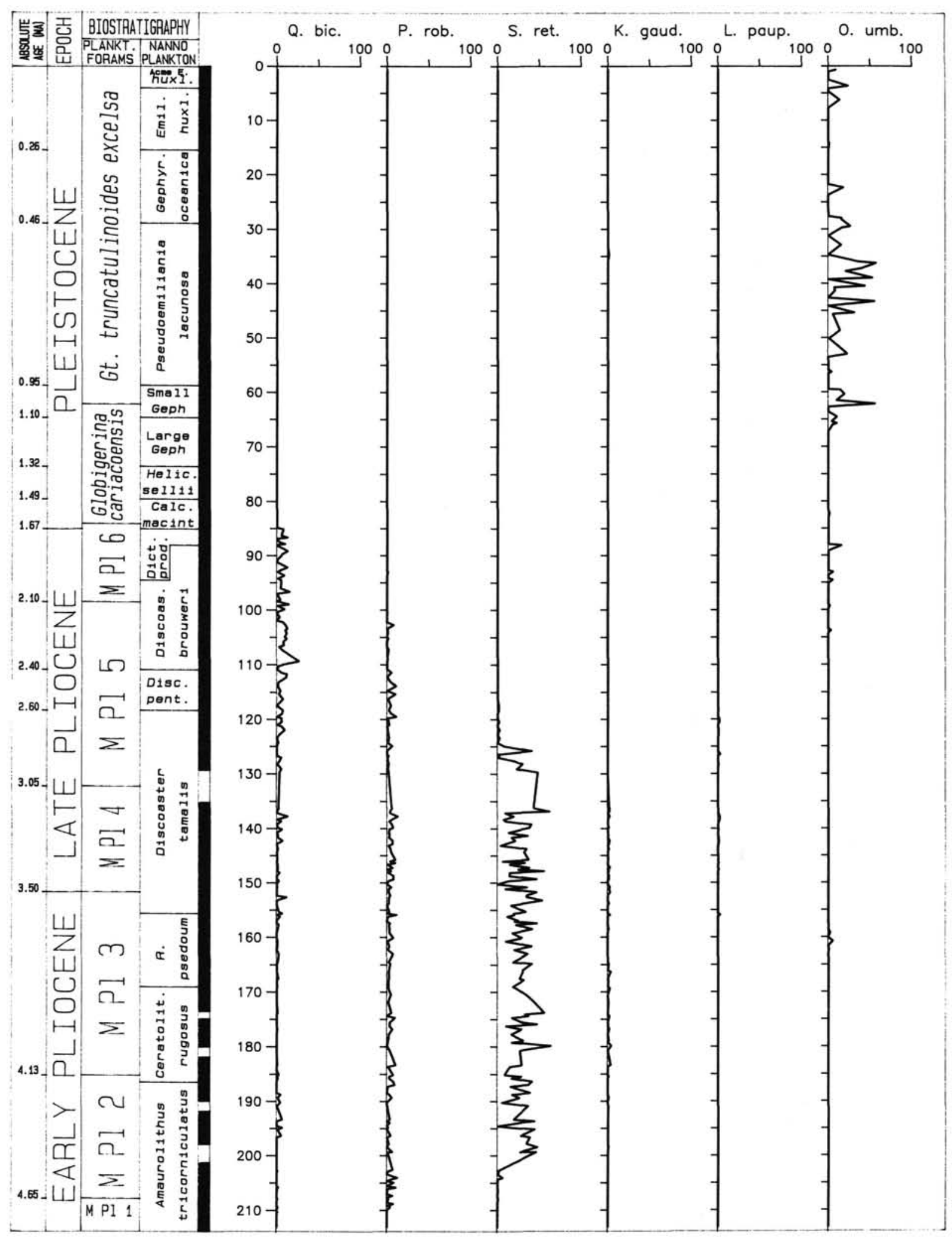

Figure 10. Frequency distribution (percentage) chart of benthic foraminifers species reported in Figure 8. Q. bic. = Quinqueloculina bicarinata $;$ P. rob. = Parrelloides robertsonianus; S. ret. = Siphonina reticulata $; \mathrm{K}$. gaud. = Karreriella gaudryinoides; L. paup. = Laticarinina pauperata; $\mathrm{O}$. umb. = Oridorsalis umbonatus. Black vertical bars $=$ recovered intervals. 


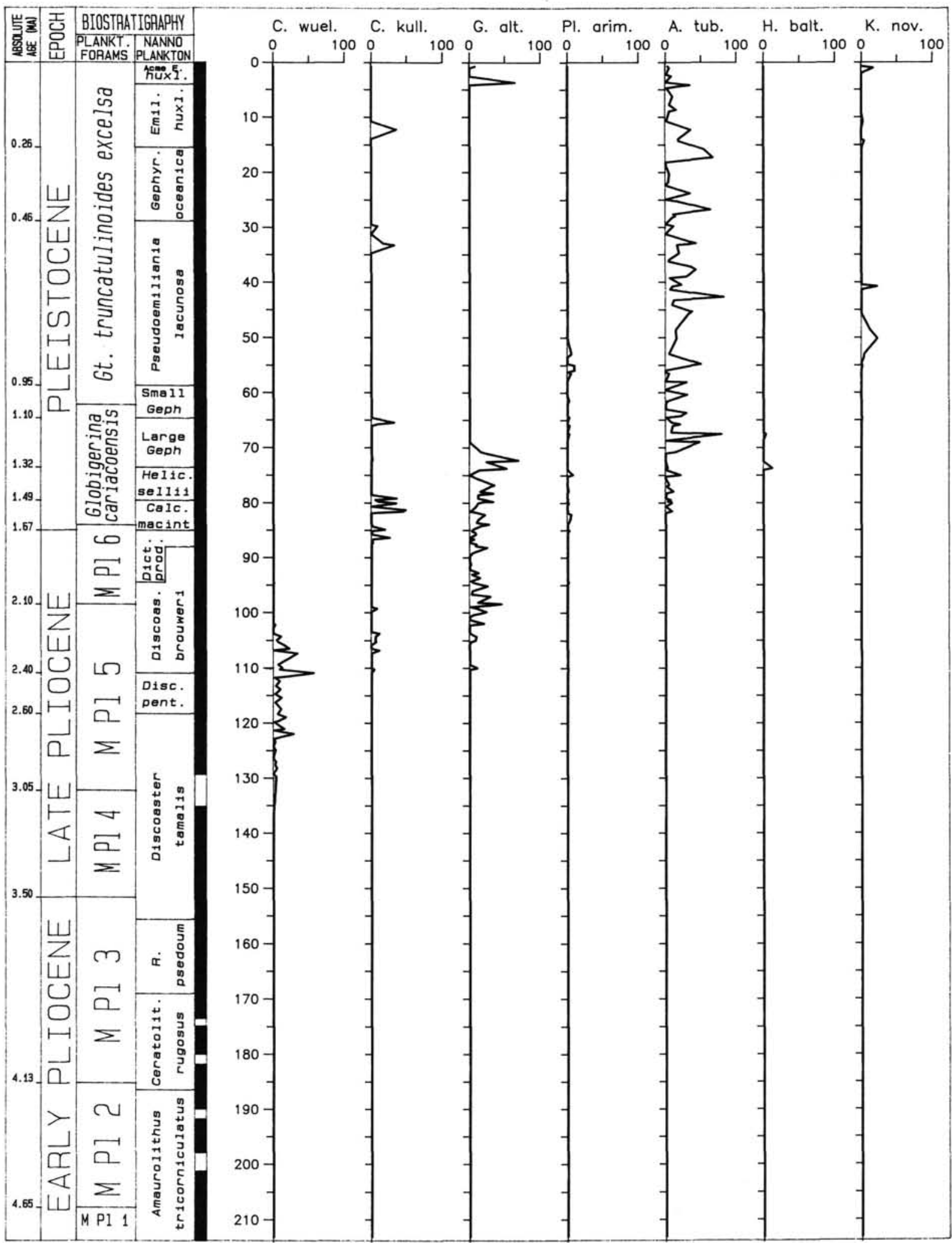

Figure 11. Frequency distribution (percentage) chart of benthic foraminifers species reported in Figure 8. C. wuel. = Cibicides wuellestorfi; C. kull. $=$ Cibicidoides kullenbergi; G. alt. $=$ Gyroidinoides altiformis; Pl. arim. $=$ Planulina ariminesis; A. tub. = Articulina tubulosa; $\mathrm{H}$. balt. = Hyalinea baltica; $\mathrm{K}$. nov. = Karreriella novangliae. Black vertical bars $=$ recovered intervals. 


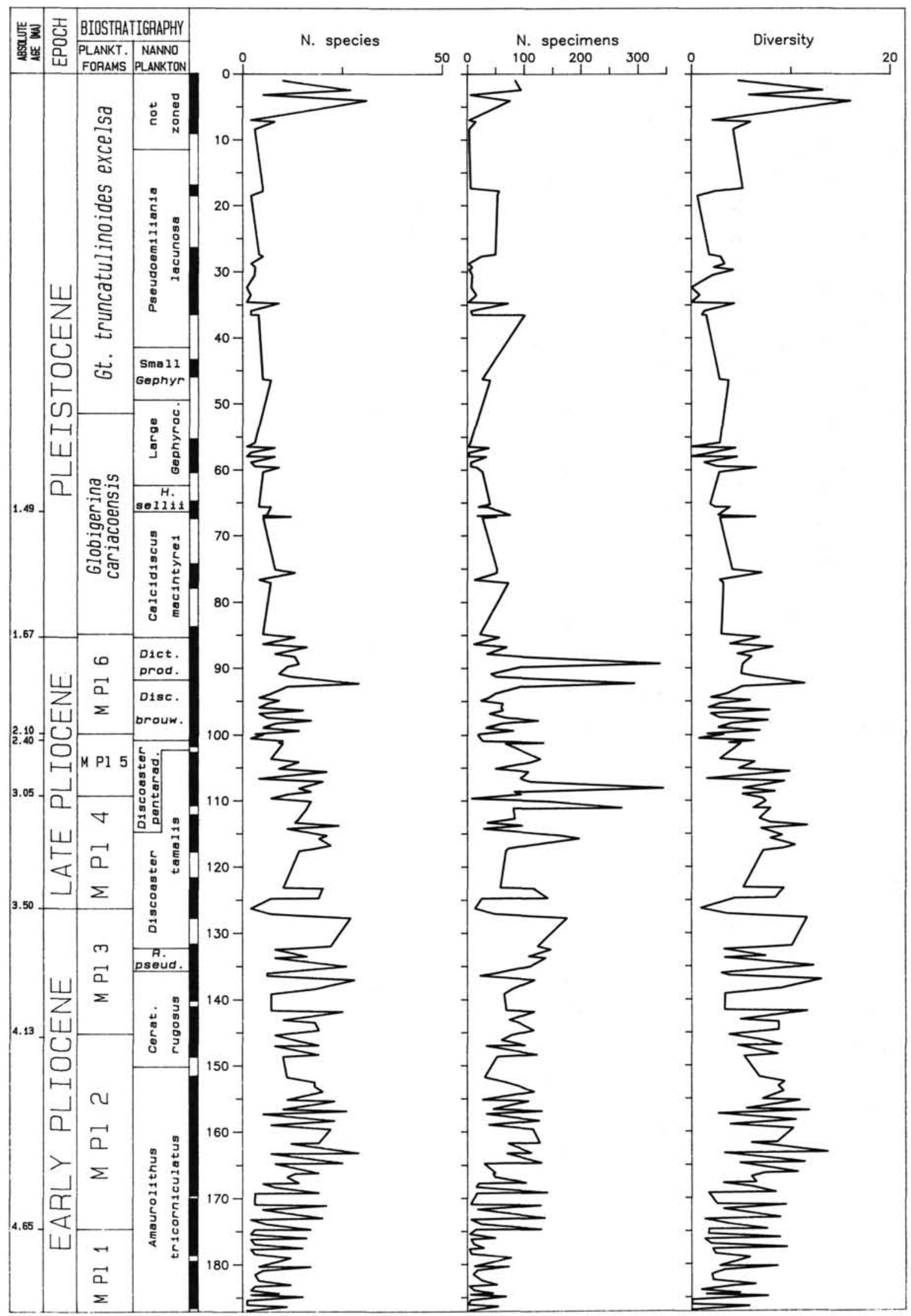

Figure 12. Plot of number of species, number of specimens, and diversity index of the benthic foraminifers in the Plio-Pleistocene sequence of Site 652 . Black vertical bars $=$ recovered intervals. 


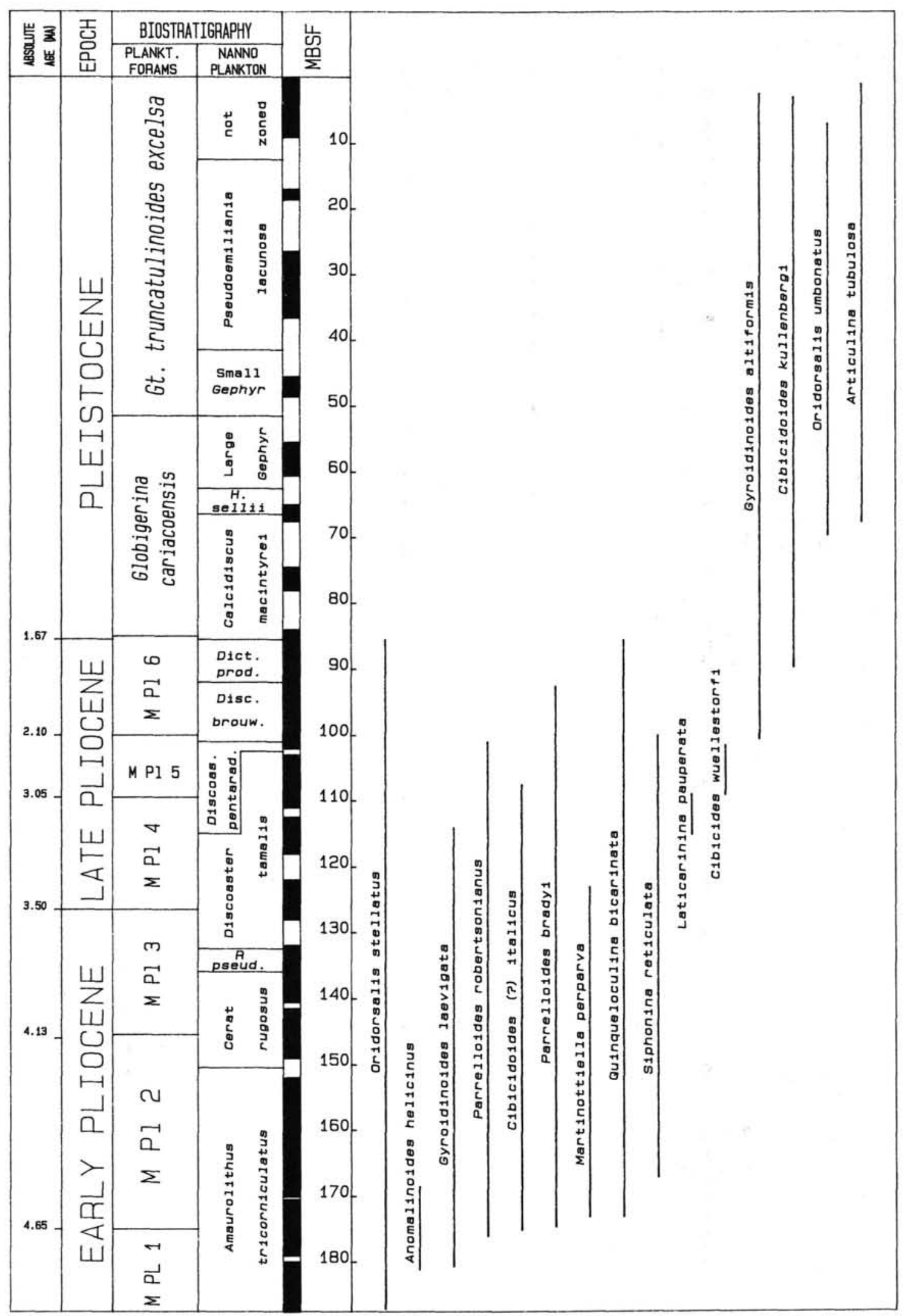

Figure 13. Stratigraphic distribution chart of the biostratigraphically most important benthic foraminifers in the Plio-Pleistocene sequence of Site 652. Black vertical bars = recovered intervals. 


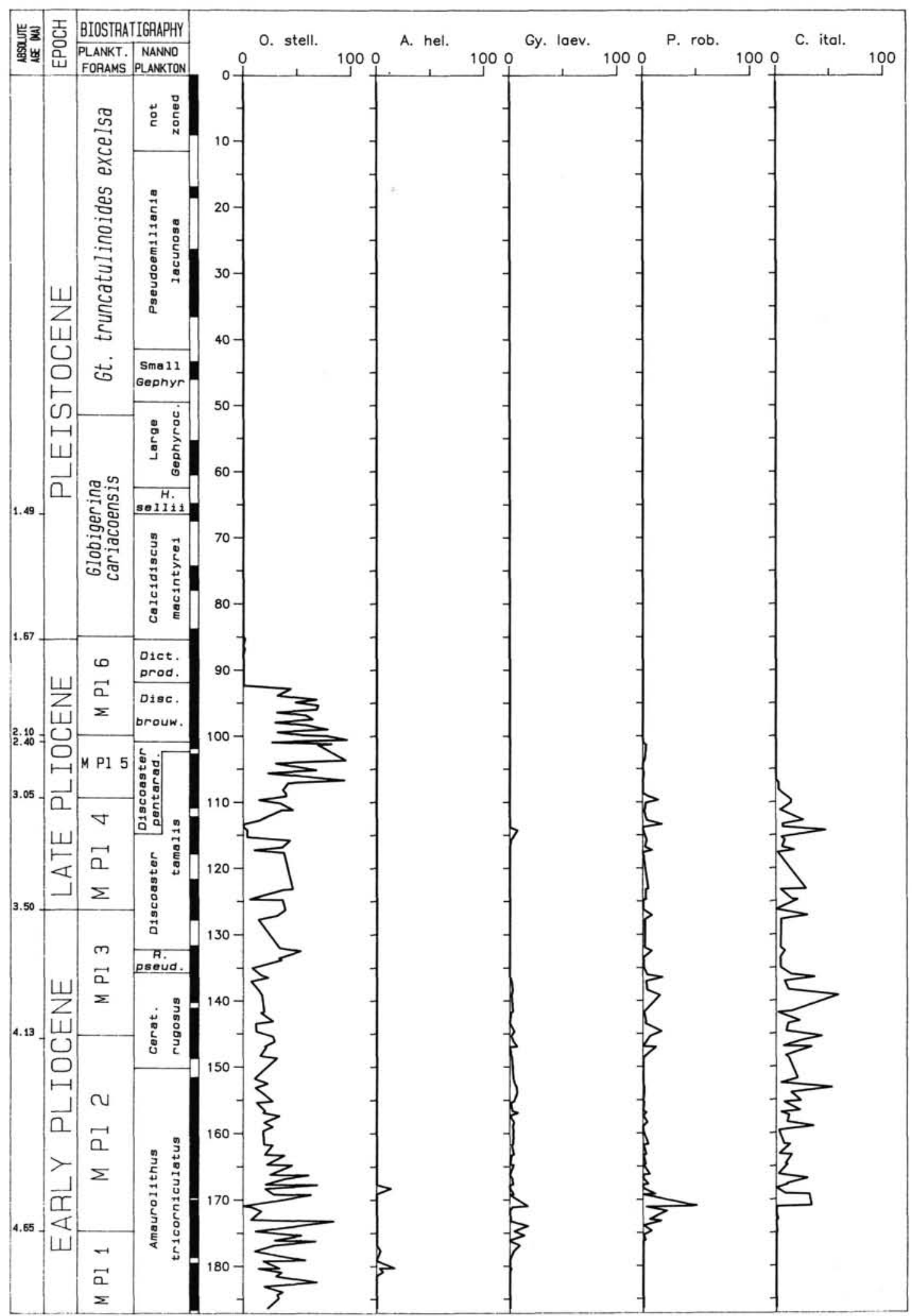

Figure 14. Frequency distribution (percentage) chart of benthic foraminifers species reported in Figure 13. O. stell. = Oridorsalis stellatus; A. hel. = Anomalinoides helicinus; Gy. laev. = Gyroidinoides laevigata; P. rob. = Parrelloides robertsonianus; C. ital. $=$ Cibicidoides(?) italicus. Black vertical bars $=$ recovered intervals. 


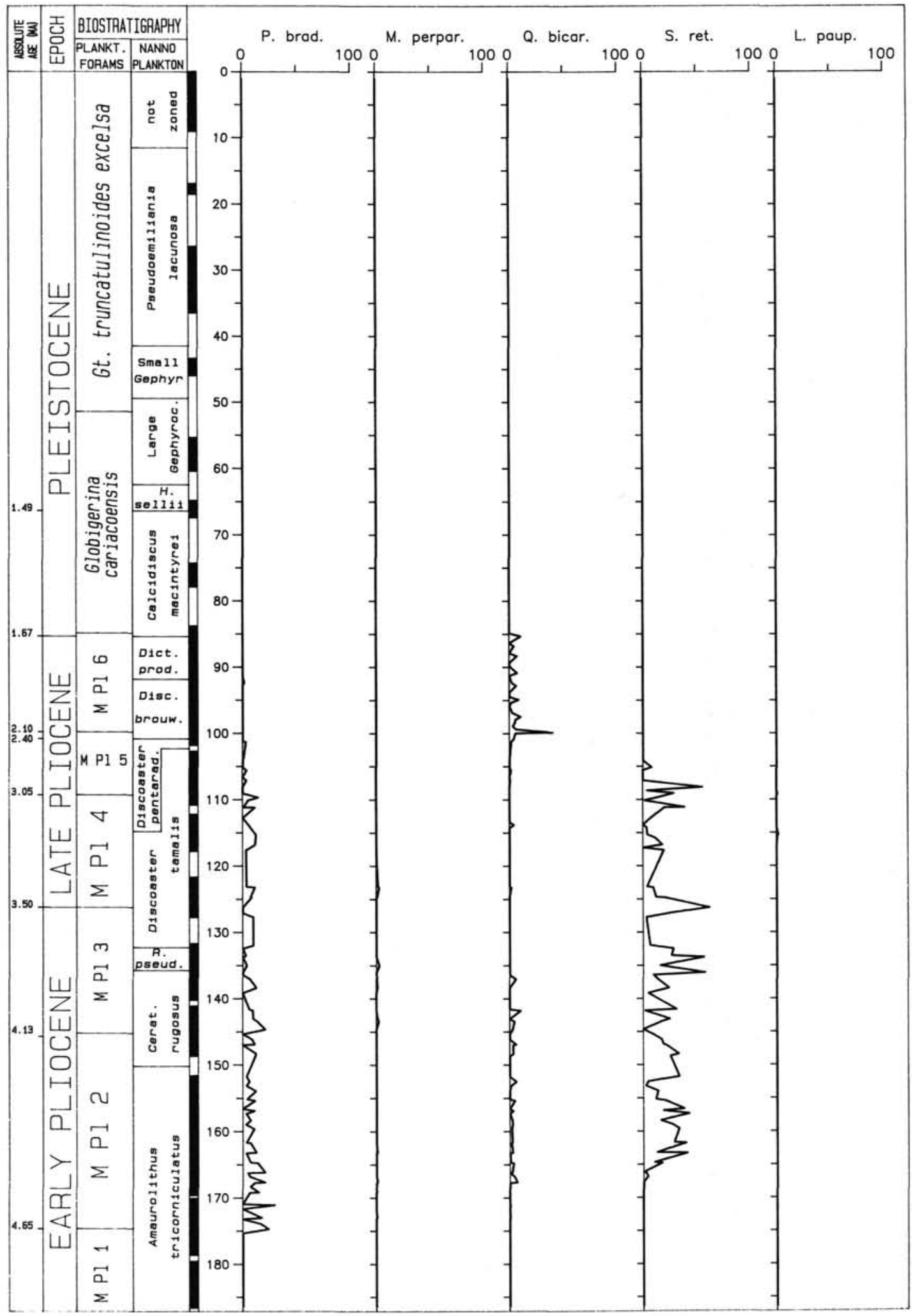

Figure 15. Frequency distribution (percentage) chart of benthic foraminifers species reported in Figure 13. P. brad. = Parrelloides bradyi, M. perpar. = Martinottiella perparva; $\mathrm{Q}$. bica. $=$ Quinqueloculina bicarinata $; \mathrm{S}$. ret. $=$ Siphonina reticulata; L. paup. = Laticarinina pauperata . Black vertical bars $=$ recovered intervals. 


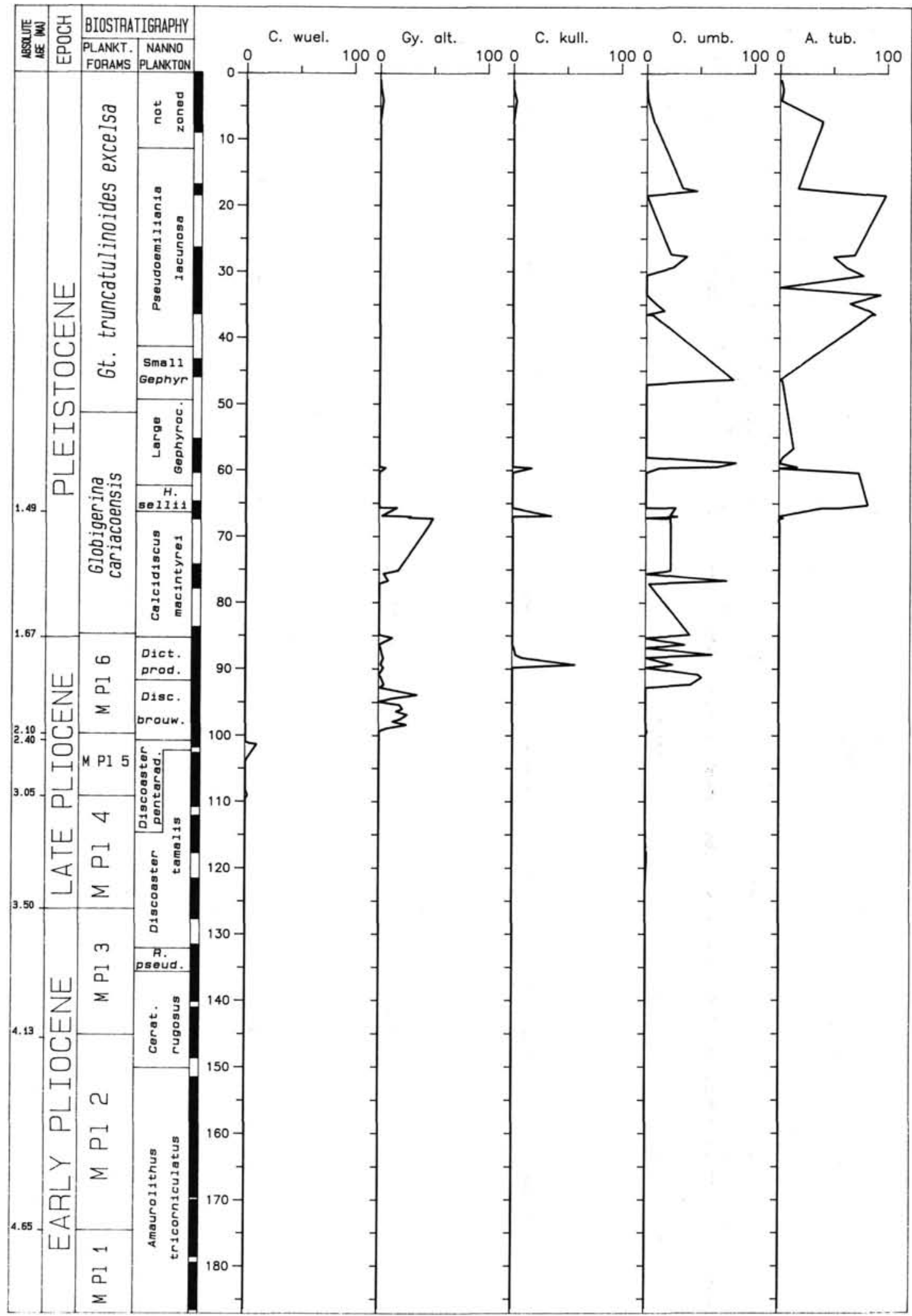

Figure 16. Frequency distribution (percentage) chart of benthic foraminifers species reported in Figure 13. C. wue. $=\mathrm{Cibi}$ cides wuellestorfi, Gy. alt. = Gyroidinoides altiformis; C. kull. = Cibicidoides kullenbergi; O. umb. = Oridorsalis umbonatus; A. tub. = Articulina tubulosa . Black vertical bars = recovered intervals. 
Tyrrhenian sites, and their distribution is not stratigraphically significant. In the three sites, the few recorded species belonging to the group of species that disappears at the top of MPl4 biozone in land sequences are definitively not present in sediments younger than the extinction level of Sphaeroidinellopsis spp. and therefore their distribution, even if not comparable, is not inconsistent with their recognized range in land sections.

During the time interval represented by the MP15 biozone, a remarkable change in the composition of the benthic foraminiferal assemblage occurs. In Site 654 the disappearance of Bolivina lucana, Bolivina lucido-punctata, Buliminella inauris, Fissurina lacunata, Martinottiella perparva, Psammosphaera testacea, Spiroloxostoma croarae in the middle lower part, the disappearance of Anomalinoides helicinus in the upper part, and the appearance of Buliminella multicamera and Rutherfordoides tenuis in the middle-upper part are correlatable with the same events in land sections (Barbieri, 1976; Sprovieri, 1978, 1985; AGIP, 1982; van der Zwaan, 1983). The last three events are included in the upper Pliocene event (van der Zwaan, 1983; Rio et al., 1984; Sprovieri, 1985), a turn-over in the benthic foraminifers assemblage which occurred at 2.3-2.2 Ma. In the other two sites this event is not recognizable. Many species that disappear in land sections at this level are missing or have disappeared at lower levels, and many species which appear at this level are not represented or first occur higher in the sections. In the upper part of the MPI5 interval, Parrelloides bradyi and $P$. robertsonianus decrease, Cibicidoides pachyderma, Cibicides wuellestorfi, Globocassidulina subglobosa, Gyroidinoides spp., Miliolids (essentially Quinqueloculina spp.), Oridorsalis stellatus, and Sigmoilopsis schlumbergeri increase and dominate more or less continuous intervals. Cibicidoides(?) italicus disappears at the base of the MPI5 biozone, respectively in Sample 15R-6, 70 $\mathrm{cm}$ (135.60 mbsf) in Site 654, in Sample $15 \mathrm{X}-2,15 \mathrm{~cm}$ (128.16 mbsf) in Site 653, and in Sample 12R-3, $116 \mathrm{~cm}$ (107.16 mbsf) in Site 652. In the three Tyrrhenian sites Siphonina reticulata disappears in this biozone. The more detailed nannofossil biostratigraphy in this stratigraphic interval is evidence that this event occurred in slightly, but significantly, different time intervals in the three sites. It disappeared first in Site 652 (Sample 12R-2, 69 $\mathrm{cm} ; 105.20 \mathrm{mbsf}$ ) at the top of the Discoaster tamalis nannofossil biozone, then in Site 653 (Sample 14X-1, $15 \mathrm{~cm} ; 117.46$ mbsf), at the base of the Discoaster pentaradiatus nannofossil biozone, and then in Site 654 (Sample 14R-1, $70 \mathrm{~cm} ; 118.40$ mbsf), near the top of the Discoaster pentaradiatus nannofossil biozone. Siphonina reticulata is found today in the Mediterranean (Parker, 1958; Bizon and Boroulet, 1984) from $80 \mathrm{~m}$ to a maximum depth of about $1000-1200 \mathrm{~m}$. The delayed disappearance from Site 652 to Site 653 and Site 654 (from east to west and from the deepest to the shallowest part of the Sardinian escarpment) may indicate the different time interval in which the three sites exceeded the depth of approximately $1200 \mathrm{~m}$. Site 652 became deeper in an older interval than Site 653 which, in turn, crossed this depth before than Site 654. In Sites 653 and 654 Gyroidinoides altiformis appears, with rare specimens, in the upper part of MP15 biozone, respectively just above and below the base of the Discoaster brouweri nannofossil biozone. In Site 652 the appearance of Gyroidinoides altiformis is well above the base of the Discoaster brouweri biozone, but this appearance level may be not coincident with the Pliocene re-entrance of $G y$ roidinoides altiformis into the Mediterranean, due to the sedimentary hiatuses detected in the interval belonging to the MPI5 in this site (Glaçon, Rio, and Sprovieri, this volume).

In the Globorotalia inflata (MP16) biozone, Quinqueloculina bicarinata and Parrelloides bradyi disappear and Cibicidoides kullenbergi is for the first time present, more or less common, in the foraminiferal assemblage of the deep-sea Tyrrhenian record, but these three events are not stratigraphically comparable in land sections, where they occur at different stratigraphic levels (AGIP, 1982).

In the Pleistocene segments two intervals can be distinguished (Figs. 2, 7, and 12). In the lower part, up to about the base of the glacial Pleistocene, above the top of the small Gephyrocapsa nannofossil biozone, the benthic assemblage is still relatively abundant and diversified, then it decreases with large fluctuations in number of species and specimens and in the diversity index; in correspondence with warm intervals, benthic assemblage is generally less abundant and less diversified, in accordance with what already recognized by Blanc-Vernet et al. (1983). In Hole 653A and in Site 652 Cibicidoides pachyderma sharply decreases in coincidence with the entrance of Cibicidoides kullenbergi (Tables 3 and 4). In Site 654 Cibicidoides pachyderma is scattered in this stratigraphic interval, but in some levels it is present with high frequencies; coincident with these peaks Cibicidoides kullenbergi is rare or absent, but is frequent in levels in which Cibicidoides pachyderma is rare or absent (Fig. 17). Cibicidoides kullenbergi is a well identified component of the NADW water masses foraminiferal assemblage today (Lohman, 1978). Peaks abundance of this species in the Pleistocene interval of Site 654 may be indicative of short, stronger influence of NADWtype water masses in the Tyrrhenian basin at the depth of Site 654 (about 2000-24000 m depth) during the Pleistocene interval, when prevailing Mediterranean-type water masses, with $\mathrm{Bo}$ livina spp., Bulimina spp., Gyroidinoides spp., Uvigerina spp., Cassidulina carina, and Cibicidoides pachyderma (cf. Parker 1958), were present.

Several species (Uvigerina costato-caudata, Articulina tubulosa, Bulimina etnea, Paromalina crassa, Rectobolivina zitteli, Loxostomum karrerianum, Paromalina coronata, Bolivinita quadrilatera) appear in land sections in the lowermost part of the early Pleistocene, below or above the first occurrence of Hyali-

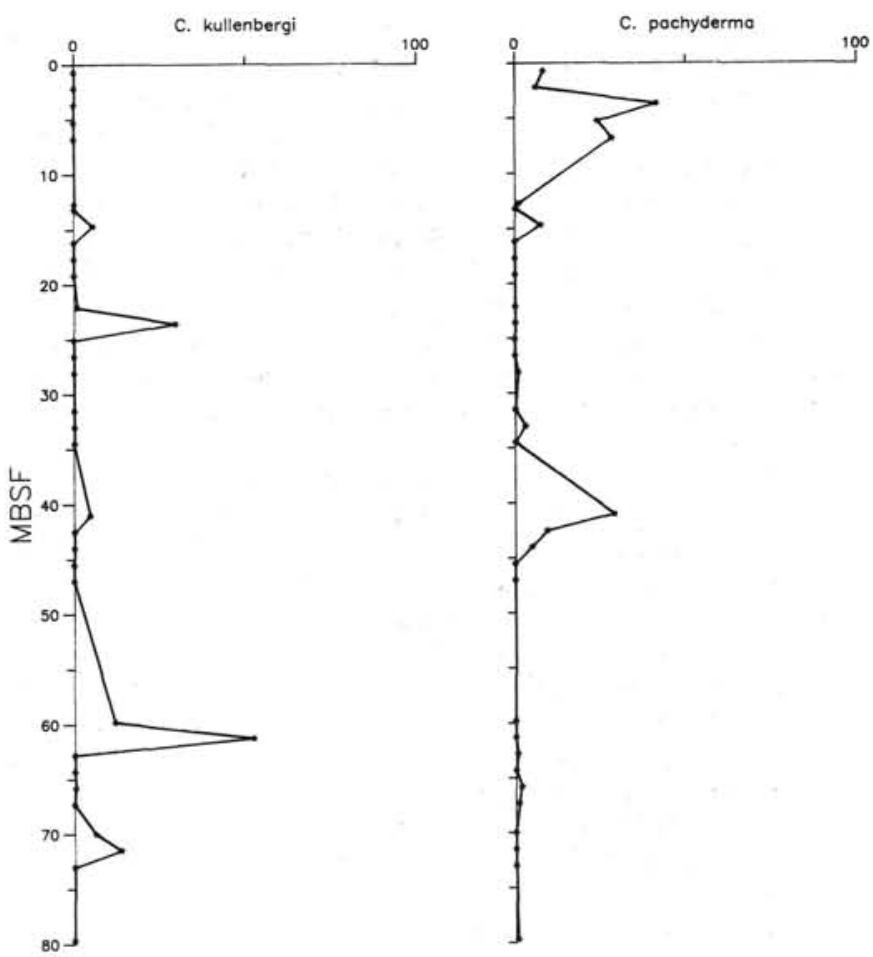

Figure 17. Frequency distribution (percentage) of Cibicidoides kullenbergi and Cibicidoides pachyderma in the Pleistocene interval of Site 654 . 
nea baltica (Sprovieri, 1978; AGIP, 1982; d'Onofrio, 1983; Sprovieri, 1985), but few of them are recorded in the Tyrrhenian deep-sea record. Only Articulina tubulosa is consistently present and common. In Hole $653 \mathrm{~A}$ it appears with small specimens in Sample $10 \mathrm{H}-3,130 \mathrm{~cm}(83.90 \mathrm{mbsf})$, at the base of the Calcidiscus macintyrei biozone, just above the Pliocene/Pleistocene boundary. In Sites 652 and 654 , this species first appears above the base of the Helicosphaera sellii nannofossil biozone, but its FO may be here not recognized due to the poor recovery in the basal part of the Pleistocene interval in these two sites. Unexpectedly, Hyalinea baltica is present and common in several samples of Site 654 and in some samples of Site 653. This species, living today from 50 to about $1000 \mathrm{~m}$ in depth (Parker, 1958; van Morkhoven et al., 1986), had evidently a wider bathymetric range during the early Pleistocene. In both sites the appearance level of this species just predates the base of the large Gephyrocapsa nannofossil biozone (Glaçon, Rio, and Sprovieri, this volume) and therefore this event in the deep-sea sequences is well comparable with the same event in land-based sequences, where it first occurs in the same biostratigraphic position (Rio, 1982; Ruggieri et al., 1984). The last occurrence of Oridorsalis umbonatus, a species not living today in the Mediterranean basin (Parker, 1958; Blanc-Vernet, 1969; Blanc-Vernet et al, 1983) is recorded in Sample 3R-3, $68 \mathrm{~cm}$ in Site 654; in Site 653 it is present up to the uppermost sample $(1 \mathrm{H}-1,75 \mathrm{~cm})$, belonging to the Emiliania huxleyi acme nannofossil biozone (Rio, Raffi, and Villa, this volume; Glaçon, Rio, and Sprovieri, this volume); in Site 652 it disappears in Sample 2R-3, $47 \mathrm{~cm}$. The last occurrence of Oridorsalis stellatus is recorded in Sample 9R-1, $70 \mathrm{~cm}$ (70.00 mbsf) in Site 654 (base of the Helicosphaera selli biozone), in Sample $8 \mathrm{H}-6,74 \mathrm{~cm}$ (68.71 mbsf) in Hole 653A (large Gephyrocapsa biozone) and in Sample 10R-1, $116 \mathrm{~cm}$ ( $85.36 \mathrm{mbsf}$ ) in Site 652 (base of the Calcidiscus macintyrei nannofossil biozone).

\section{BENTHIC FORAMINIFER BIOSTRATIGRAPHY}

Benthic foraminifers zonal schemes for the Italian Plio-Pleistocene sequences have yet been proposed (AGIP, 1982; Colalongo and Sartoni, 1979; Colalongo et al., 1982) (Fig. 18) and compared with planktonic foraminifers zonal schemes. Since no reference to nannofossil biostratigraphy is given, the stratigraphic and biochronological identification of their zonal boundaries are often not well detailed. These benthic foraminifers biostratigraphic schemes could not be adopted in the deep-sea Tyrrhenian record since they are based on zonal markers that are rare, scattered, and diachronous (Uvigerina rutila, Anomalinoides helicinus) or not present at all (Bulimina marginata, Bulimina elegans marginata) in the deep-sea sequences of the three Tyrrhenian sites.

In the Tyrrhenian sequences the range of many benthic foraminiferal species is controlled by environmental changes, essentially increasing bathymetry, and, from the upper part of the Pliocene, decreasing oxygen bottom content (Hasegawa, Sprovieri, and Poluzzi, this volume). But a few species show a consistent and comparable stratigraphic distribution among the three sites and therefore appear as useful markers to establish a biostratigraphic zonal scheme. As they show comparable stratigraphic distribution in several land sections (Sprovieri, 1978; Colalongo and Sartoni, 1979; AGIP, 1982; d'Onofrio, 1983; Sprovieri, unpubl. data), a zonal scheme based on these species may be recognized also in land sequences. Their zonal boundaries are surely not as strictly isochronous as the calcareous plankton zonal boundaries, and local paleoenvironmental and paleoecological changes may have great influence on the stratigraphic distribution of the zonal markers, but they can be assumed as useful events to characterize broad intervals in the distribution of the Plio-Pleistocene benthic foraminifers assemblage. The identification of the adopted zonal markers is based on some preliminary assumptions and considerations. Data on their stratigraphic distribution from land sections have been considered (AGIP, 1982; Colalongo and Sartoni, 1979; Colalongo et al, 1982; Sprovieri, 1978, 1979, 1985; d'Onofrio, 1983; Sprovieri, unpubl. data). Biochronology of the events used as zonal boundaries has been evaluated by interpolation between the nearest underlying and overlying calcareous plankton events, with reference to the calcareous plankton biostratigraphy and biochronology available for the considered sequences, and assuming constant sedimentation rates within the considered intervals. When values were found within a range of 0.1-0.2 m.y., events were considered synchronous. Since FO's and LO's are generally represented by rare and scattered specimens (Figs. 4-6, 9-11, 14$16)$, sedimentary hiatuses and poor recovery may have great influence in their identification and were therefore considered and discussed. From the data reported in Figures 3, 8, and 13 and in Tables 2-4, different, apparently better, zonal markers, whose bases and tops are biochronologically tightly grouped in the three sites may be identified, as the base of Cibicides wuellestorfi and the top of Cibicidoides brady. Nevertheless, when compared with other Italian land sequences, these events result well diachronous (AGIP, 1982; Bonfornello (Northern Sicily), Sprovieri, 1977; Capo Rossello (Southern Sicily), Sprovieri, 1978, and Rio et al. 1984; Gela (Southern Sicily), Sprovieri, unpubl. data). Five intervals are tentatively proposed. They are discussed below and compared with calcareous plankton biostratigraphic schemes (Fig. 19).

\section{Cibicidoides(?) italicus Assemblage Zone}

The basal boundary of this zone is coincident with the base of the Pliocene, defined by the re-establishment of a permanent marine faunistic assemblage (Cita, 1975). The upper boundary is coincident with the extinction level of the nominal taxon. The biochronological evaluation of this event is at $2.82 \mathrm{Ma}$ in Hole 653A, 2.9 Ma in Site 654, 2.92 Ma in Gela (Sprovieri, unpubl. data), and 2.91 Ma in Punta Piccola (Sprovieri and Barone, 1982; Rio et al. 1984). Therefore a biochronological age of 2.9 $\mathrm{Ma}$ is assumed for this event. The discontinuous record in the interval of MPl5 in Site 652, with at least two long hiatuses (Glaçon, Rio, and Sprovieri, this volume) does not allow a reliable biochronologic evaluation of this event. In Site 654 the disappearance level of Cibicidoides(?) italicus is only about $0.7 \mathrm{~m}$ above the top of Kaena magnetic polarity subchron, recognized (Channell et al., this volume) at 136.30 mbsf. In Site 652 the extinction level of this species was detected just below the top of the Kaena subchron, recognized (Channell et al., this volume) at 106 mbsf. The good correlation with these paleomagnetic data represents a strong support to the proposed biochronological evaluation of the extinction level of Cibicidoides(?) italicus. In the very basal segment, belonging to the MPI1 and basal MPI2 planktonic foraminifers biozones, the marker is generally missing or very rare and the benthic foraminiferal assemblage, still not diversified, is dominated by Globocassidulina subglobosa, Oridorsalis stellatus, and Uvigerina pygmaea, indicative of slightly under-oxygenated bottom conditions (Hasegawa, Sprovieri, and Poluzzi, this volume; Mckenzie and Sprovieri, this volume). In the long following interval, stable, well-oxygenated, epibathyal marine conditions are recognized, with more or less frequent and consistent influence of NADW (North Atlantic Deep Water) water masses (Hasegawa, Sprovieri, and Poluzzi, this volume). In the long interval belonging to this biozone a strong increase in the number of species gradually occurs. In land sections Nodosarids are frequent in the faunistic assemblage of this interval, and decrease in coincidence with the mid-Pliocene event, at about 3.2-3.1 Ma (Rio et al., 1984; Sprovieri, 1985). The extinction level of the zonal marker is generally abrupt (Figs. 5, 9, 


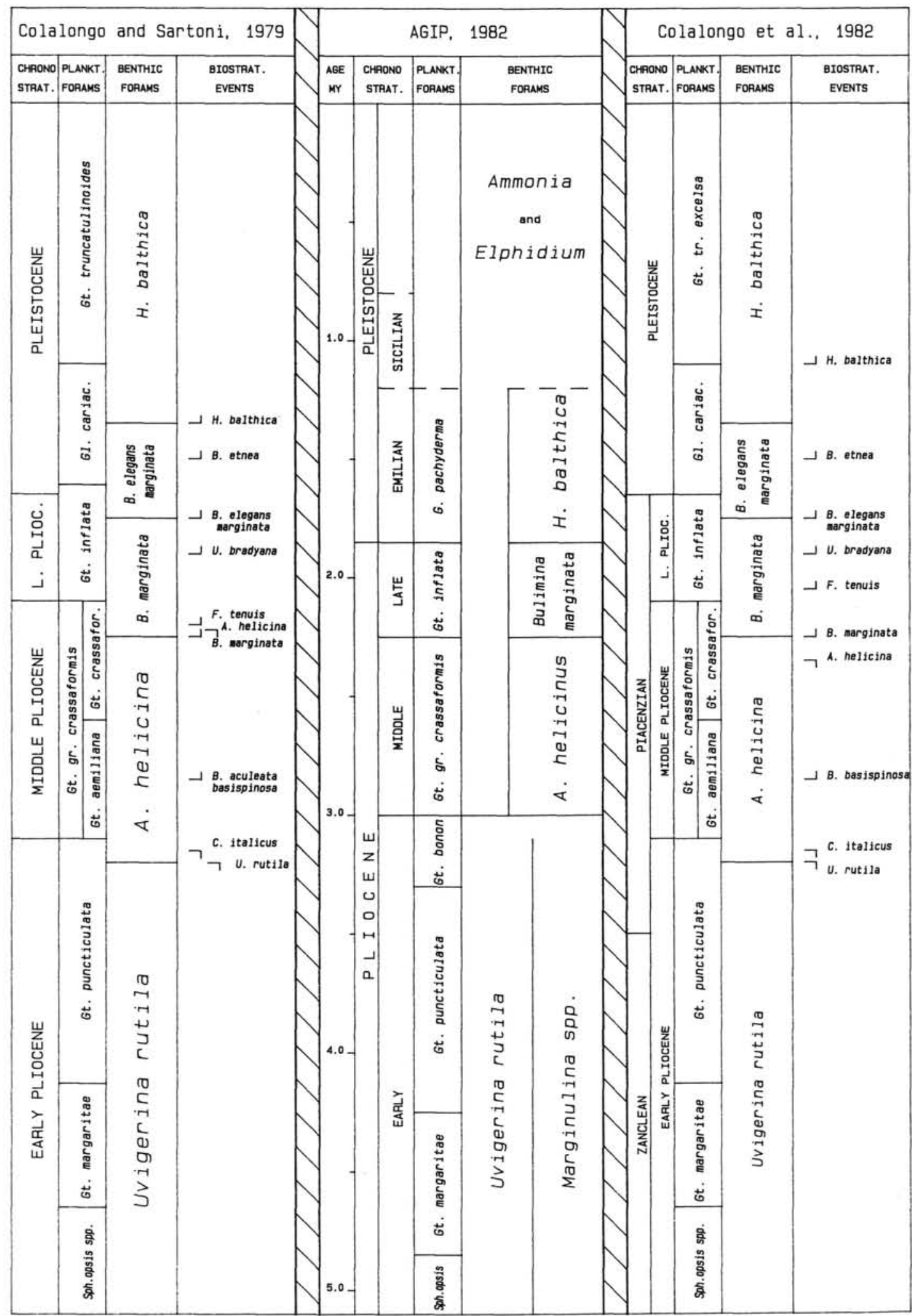

Figure 18. Benthic foraminifers zonal schemes for the Italian Plio-Pleistocene record. 


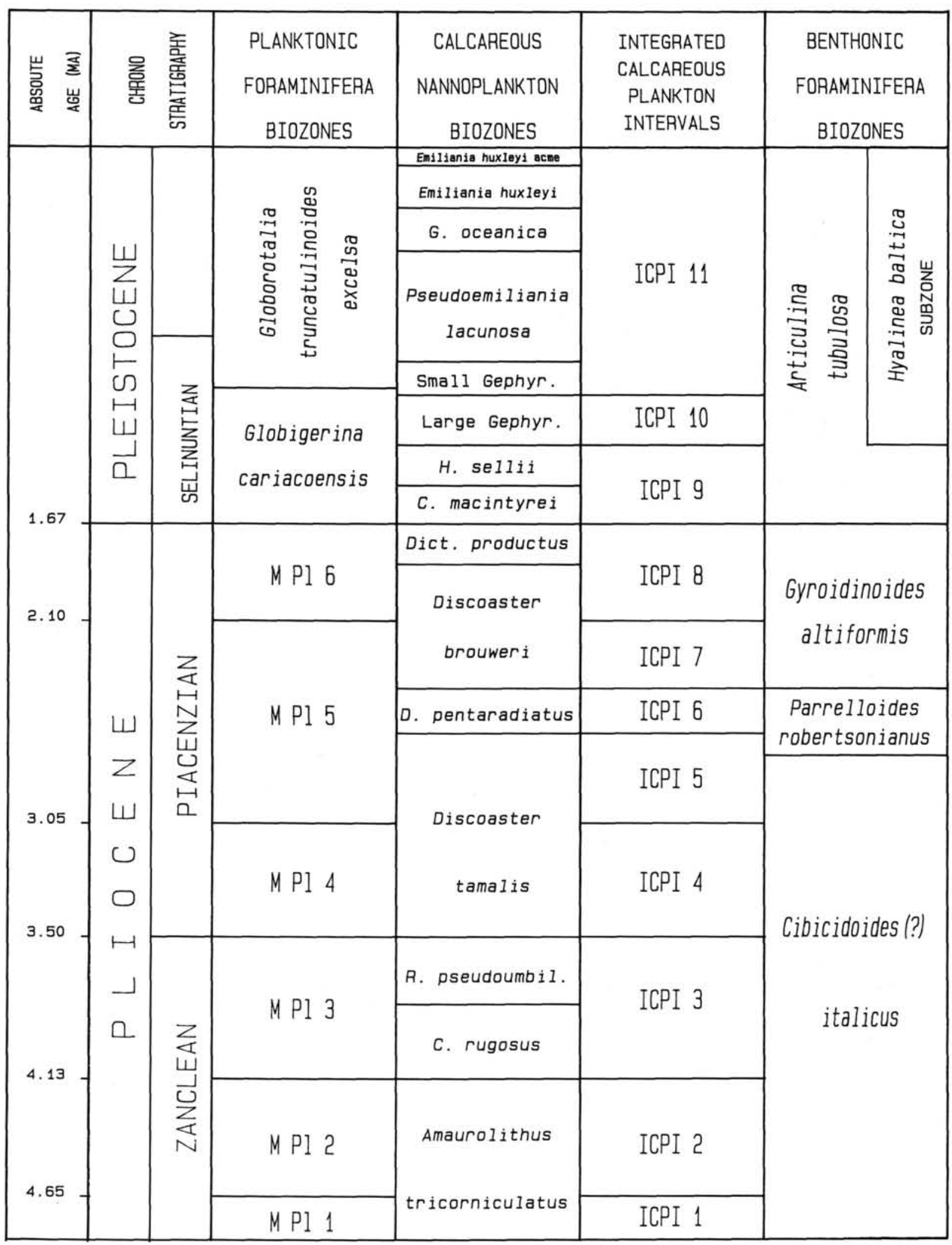

Figure 19. Mediterranean Plio-Pleistocene benthic foraminifers biostratigraphic scheme proposed in this paper (right column) and correlation with calcareous plankton biostratigraphic schemes. Plankton foraminiferal biozones from Cita (1973, 1975), as emended by Rio et al. (1984); calcareous nannofossil biozones from Rio, Raffi, and Villa (this volume) and Glaçon, Rio, and Sprovieri (this volume); integrated calcareous plankton intervals from Rio et al. (1984) and Rio and Sprovieri (1986). 
and 14) and therefore easily recognizable both in the deep-sea record and in the Italian land sections.

\section{Parrelloides robertsonianus Interval Zone}

The base of this interval is coincident with the extinction of Cibicidoides(?) italicus. The top of the zone is coincident with the Pliocene re-entrance of Gyroidinoides altiformis into the Mediterranean basin. The biochronological evaluation of this event is at 2.37 Ma in Site 653A, 2.5 Ma in Site 654, 2.42 Ma in Capo Rossello (reported as Gyroidinoides longispira in Sprovieri, 1978), and $2.34 \mathrm{Ma}$ in Gela (Sprovieri, unpubl. data). In Site 652 it was not calibrated, due to the sedimentary hiatuses in the MP15 interval of this sequence (Glaçon, Rio, and Sprovieri, this volume). A biochronological evaluation of $2.4 \mathrm{Ma}$ is assumed for this event. In this interval the nominal taxon (with Parrelloides bradyi and intermediate morphotypes) is well represented, as consequence of the intensification of NADW influence in the Mediterranean basin, due to the progressively increasing depth of the Tyrrhenian basin (Hasegawa, Sprovieri, and Poluzzi, this volume). The top of this zone approaches the base of the "Glacial Pliocene," evaluated at 2.47 Ma by Shackleton et al. (1984).

\section{Gyroidinoides altiformis Interval Zone}

The base of this interval is defined by the Pliocene re-entrance into the Mediterranean basin of the zonal marker. Its top coincides with the appearance of Articulina tubulosa. The nominal taxon is a common species in the upper Miocene Mediterranean sequences (AGIP, 1982), but is absent in most of the Pliocene. It reappears in the upper part of MPI5 planktonic foraminifers biozone, when it is again an important constituent of the Mediterranean benthic foraminiferal assemblage. In the lower part of this interval, below the entrance of Globorotalia inflata, the last occurrence of Anomalinoides helicinus and, in land sections, the first occurrence of Bulimina marginata and Rutherfordoides tenuis are recorded (Sprovieri, 1978; AGIP, 1982; Colalongo and Sartoni, 1979; Colalongo et al., 1982). These events are included in the turn-over in the benthic foraminifers assemblage which in the Mediterranean basin identifies the upper Pliocene event (van der Zwaan, 1983; Rio et al. 1984; Sprovieri, 1985; Rio and Sprovieri, 1985) at about 2.3-2.2 Ma. From the base of this interval the number of species and the diversity index decrease (Figs, 2, 7, and 12). The first indication of reduced oxygen bottom conditions, still in a stratigraphic interval dominated by NADW assemblage, start from the base of this biozone in Site 653 and Site 654 , and water masses similar to the present-day Mediterranean bottom water for the first time occupied the Tyrrhenian basin (Hasegawa, Sprovieri, and Poluzzi, this volume). In land sections (Capo Rossello and Gela) (Sprovieri, 1978; Rio and Sprovieri, 1985; Sprovieri et al, 1986; Sprovieri, unpubl. data) in this stratigraphic interval laminated and/ or sapropelic levels are frequent and physical/chemical conditions at the bottom changed consistently, with a shift toward oxygen-deficient environment (van der Zwaan, 1983). The basal boundary of this biozone is well recognizable in the deep-sea and land sequences, even if weakly defined since it is based on a species which is rare at the base and which re-entered into the Mediterranean basin in the upper part of the Pliocene, after its exit from this basin in the upper part of the Miocene. Gyroidinoides altiformis is the only benthic foraminifers species whose stratigraphic distribution can be consistently correlated in this part of the Pliocene both in the land and deep-sea sequences.

\section{Articulina tubulosa Assemblage Zone}

The base of the interval is coincident with the appearance of the nominal taxon. The top is coincident with the Recent. The appearance level of Articulina tubulosa is biochronologically evaluated at $1.6 \mathrm{Ma}$ in Hole $653 \mathrm{~A}$, in which a small hiatus is present at the Plio-Pleistocene boundary level (Glaçon, Rio, and Sprovieri, this volume), at $1.62 \mathrm{Ma}$ in DSDP Site 125 (Leg 13) (Raffi and Sprovieri, 1984), at $1.71 \mathrm{Ma}$ in the Vrica section (d'Onofrio, 1983; Rio et al., 1988). In Site 654 and in Site 652 this event is evaluated at about $1.49 \mathrm{Ma}$, but it is preceded in the two sequences by long intervals with very poor recovery, and therefore the first occurrence of this species in these sequences may be not recorded. In DSDP Site 132 (Leg 13) Articulina tubulosa is present from Core 7 (54-63 mbsf) (Ryan et al., 1973). No detailed indications of the range of this species are given, but also in this site the appearance of Articulina tubulosa can be evaluated just above the base of the Calcidiscus macintyrei biozone, recognized in Section 8-1 (Raffi and Rio, 1979). A biochronological age of about $1.62 \mathrm{Ma}$ is assumed for the appearance level of Articulina tubulosa. It is therefore correlatable with the Pliocene/Pleistocene boundary, as defined in the Vrica section (Calabria, Italy) (Aguirre and Pasini, 1985). This species is generally abundant in deep-sea sediments, sometime with welldeveloped specimens characterized by a very long tubular segment. A decrease in the number of species and specimens and in the diversity index is recorded in the three sites at the base of the Plio/Pleistocene boundary (Figs. 2, 7, and 12), practically coincident with the base of this biozone. This event may be correlated with the increasing well-oxygenated bottom conditions recognized at the base of the Pleistocene (Hasegawa, Sprovieri, and Poluzzi, this volume). Articulina tubulosa is a bathyal species (Parker, 1958; Blanc-Vernet, 1969; Wright, 1978a), and therefore the basal boundary of this biozone is better recognized in deep-sea and bathyal sequences. In sequences deposited in shallower depth environment this boundary can be approximated by the appearance level of Bulimina elegans marginata (Colalongo and Sartoni, 1979; Colalongo et al., 1982; d'Onofrio, 1983) and Uvigerina costato-caudata (Sprovieri, 1981) slightly below, and by the appearance of Bulimina etnea (Sprovieri, 1978; Colalongo and Sartoni, 1979; Colalongo et al, 1982; d'Onofrio, 1983) above.

\section{Hyalinea baltica Assemblage Subzone}

The base of the interval is coincident with the appearance of the nominal taxon. The top is coincident with the Recent. The biochronological evaluation of the appearance level of Hyalinea baltica is at 1.35 Ma in Hole 653A and in Site 654, where it is recorded in the upper part of the Helicosphaera sellii nannofossil biozone, slightly predating the base of the large Gephyrocapsa biozone. In land sections this event also occurs in the upper part of the Helicosphaera sellii nannofossil biozone, just below the first appearance level of the large Gephyrocapsa (Rio, 1982; Ruggieri et al., 1984) and is therefore synchronous with the same event in the deep-sea Tyrrhenian record. Hyalinea baltica is essentially a neritic and epibathyal species (Parker, 1958; Wright, 1978a), and therefore the base of this subzone is easily recognized in land sections where $H$. baltica represents a frequent element of the foraminiferal benthic assemblage from this level up to the Recent (Ruggieri et al., 1984; Parker, 1958). In the deepsea Mediterranean record this zonal boundary is less frequently recognized, since Hyalinea baltica is rare, scattered, or absent in the most sequences (ODP Leg 107, Sites 650, 651, 652, 655; DSDP Leg 13 (Ryan et al., 1973), DSDP Leg 42A (Wright, 1978a). The first appearance level of Hyalinea baltica well above the base of the Pliocene-Pleistocene boundary as defined in its type section, is coincident with the lithologic level which defines the base of the Emilian substage in its type section (Santerno section, Emily region, Italy) (Ruggieri et al., 1975) and discriminates the underlying Santernian from the Emilian sediments. 


\section{TAXONOMIC AND BIOSTRATIGRAPHIC NOTES}

\author{
Articulina tubulosa (Seguenza)
}

Quinqueloculina tubulosa Seguenza, 1862, Accad. Gioenia Sci. Nat. Catania, ser. 2 , vol. 18 , p. 119 , pl. 2 , fig. 8 .

This species is a persistent and frequent element of the Pleistocene deep-sea benthic assemblage in the Mediterranean basin. It is characterized by having the last chambers arranged in more or less long, uniserial, tubular form; smaller specimens, with reduced quinqueloculine stage, generally display longer tubular arrangement of the last chambers. Sometime the uniserial part of the test is broken off, and the specimens may be misidentified with Quinqueloculina (essentially Quinqueloculina venusta), but a careful examination of the apertural region of these specimens reveals the break. This species appears close to the PlioPleistocene boundary and is definitively not present in older sediments.

\section{Cibicides wuellestorfi (Schwager)}

(Plate 5 , Figs. 10-12)

Anomalina wuellestorfi Schwager, 1886, Novara Exped., Geol. Theil, vol. 2, no. 2, p. 258, figs. $105,107$.

This species in generally not abundant in the Tyrrhenian sites; in the three sites it is present only in the MP15 biozone, from just below the last occurrence of Siphonina reticulata to just above the appearance of Gyroidinoides altiformis. Our specimens have a strongly compressed, trochospiral, glassy test with a flat or slightly concave spiral side and a moderately convex ventral side; the aperture is slit-like at the base of the apertural face and extends onto the spiral side.

\section{Cibicidoides(?) italicus (Di Napoli)}

(Plate 5, Figs. 7-9)

Cibicides italicus Di Napoli, 1952, Riv. Ital. Paleontol., vol. 58, p. 1-16, pl. 1.

This very characteristic and stratigraphically useful species is known only in the Mediterranean basin. It is tentatively ascribed to Cibicidoides considering its highly vaulted spiral side, the granular aspect of the umbilical region, the very fine pores on the spiral side, and the aperture restricted to the umbilical side. It is frequent in late Miocene (AGIP, 1982) and early to middle late Pliocene stratigraphic intervals and disappears well below the Discoaster tamalis extinction level (Glaçon, Rio, and Sprovieri, this volume; Rio, Raffi, and Villa, this volume) at about $2.9 \mathrm{Ma}$.

\section{Cibicidoides kullenbergi Parker}

(Plate 4, Figs. 22-24)

Cibicidoides kullenbergi Parker, 1953, Swedish Deep-Sea Exped., vol. 7, no. 1 , p. 49 , pl. 11 , figs. 7,8 .

Our specimens are characterized by a trochospiral test with the umbilical side more convex than the spiral side, which is completely covered by a translucent, glassy thickening with few relatively large pores; a distinct, rounded keel is present around the periphery; on the umbilical side the intercameral sutures are flush with the surface, strongly limbate, and strongly recurved backward; the umbilicus is closed by a large, flush glassy knob. In the three sites the species is present only in the Pleistocene and the uppermost Pliocene. In older sediments it may be confused with specimens of Cibicidoides agrigentinus (Schwager) which can be distinguished by its more flat, equally biconvex test, less rounded keel, less limbate and less recurved ventral sutures, and a smaller umbilical knob. In all the samples in which Cibicidoides kullenbergi has its maximum abundance, Cibicidoides pachyderma abundance sharply decreases.

\section{Cibicidoides ornatus (Costa)}

(Plate 4, Figs. 6-8)

Nonionina ornata Costa, 1856, Atti Acc. Pont., vol. 7, p, 203, pl. 17, figs. $17 \mathrm{a}-\mathrm{c}$.

This generally common species in the Mediterranean Pliocene and Pleistocene sediments is referred to Cibicidoides for its slit-like, peripheral aperture at the base of the last chamber extending onto the spiral side. Van Morkhoven et al. (1986) list this species as a suspected synonym of Cibicidoides incrassatus (Fichtel and Moll), an Oligocene to Recent species. Even if the two taxa are quite similar, we prefer to consider
Cibicidoides ornatus as a distinct form for its non-limbate umbilical sutures, less recurved intercameral sutures on the spiral side, less regular and less flat spiral knob perforated by smaller pores, and the more rounded periphery without a clear imperforate band. This species disappears at different levels of the Pliocene in the Tyrrhenian deep-sea record, but it ranges to Pleistocene in land-based sequences (AGIP, 1982; d'Onofrio, 1983).

\section{Cibicidoides pachyderma (Rzehak)}

(Plate 4, Figs. 9-11)

Truncatulina pachyderma Rzehak,1886, Naturf. Ver. Brunn, Verh., vol. 24 , p. 87 , pl. 1 , fig. 5 .

The subequal trochospiral test, with subcarinate, non-lobate periphery (but lobate in the last chambers of the large specimens) has the spiral side covered by a calcite lamina which completely masks the dorsal sutures.

\section{Eggerella bradyi (Cushman)}

(Plate 1, Figs. 7-8)

Verneuilina bradyi Cushman, 1911, U.S. Nat. Mus. Bull., no. 71, p. 54, fig. 87 .

The species has a small, subconical, inflated, finely agglutinated, triserial test. It may be confused with immature specimens of Karreriella bradyi (Cushman) in which the biserial final ontogenetic stage is not developed. Even if Karreriella bradyi generally has a little more coarsely agglutinated surface, the two species may sometimes have been confused together in the specimen count.

\section{Gyroidinoide altiformis Stewart and Stewart}

Gyroidina soldanii d'Orbigny var. altiformis Stewart and Stewart, 1930, J. Paleont, vol. 4, no. 1, p. 67, pl. 9, fig. 2.

The species has a high trochospiral test, with oblique intercameral sutures on the spiral side, acute periphery, and open, deep umbilicus. It is a common element of the Miocene sediments (AGIP, 1982); it is not present in lower and basal upper Pliocene interval, and it re-entered the Mediterranean basin in the upper part of the Pliocene (upper part of the MPI5 planktonic foraminiferal biozone), quite coincident with the glacial Pliocene event (at about 2.4 Ma), and is living in the Mediterranean basin today (Parker, 1958).

\section{Gyroidina cf. neosoldanii (Brotzen)}

Gyroidina neosoldanii Brotzen, 1936, Sver. Geol. Unders., ser. C (no. 396), Stockholm, Sweden, v. 30, no. 3, p. 158.

In the complicated taxonomy of Gyroidina soldanii (d'Orb.) and Gyroidina neosoldanii (Parker 1958; Todd, 1958; Lohman, 1978), the concept of Parker (1958) is followed here, including specimens with slightly compressed tests, subacute periphery, small almost closed umbilicus, and radial sutures.

\section{Oridorsalis umbonatus (Reuss)}

(Plate 2, Figs. 4-6)

Rotalina umbonata Reuss, 1851, Deutsch Geol. Ges., Zeitschr., vol. 3, p. 75 , pl. 5 , fig. 35 .

In our samples the species is generally common; rare specimens with an acute periphery designated as Truncatulina tener by Brady, from which Oridorsalis umbonatus can hardly be distinguished (Lohman, 1978; Corliss, 1979), are included. We consider Oridorsalis umbonatus distinguished from Oridorsalis stellatus (Silvestri) which is characterized by prominent stellate sutures around the umbilicus. The two species have different stratigraphic ranges: Oridorsalis stellatus is common in the Pliocene (and pre-Pliocene) interval and disappears in the basal Pleistocene, just below the appearance of Hyalinea baltica. Oridorsalis umbonatus is more frequent from the uppermost Pliocene and disappears from the Mediterranean basin in the upper part of the NN21 nannofossil biozone. Parker (1958), Blanc-Vernet (1969), and Blanc-Vernet et al. (1983) have all demonstrated that this species is not present in the Mediterranean uppermost Pleistocene and Recent sediments. Its stratigraphic distribution makes it possible to recognize the presence of $\mathrm{Re}$ cent or sub-Recent sediments in the Mediterranean top cores, where this form is not present. 
Parrelloides bradyi (Trauth)-Parrelloides robertsonianus (Brady) (Plate 5, Figs. 1-6)

Truncatulina bradyi Trauth, 1918, K. Akad. Wiss. Wein. Math. Naturw. Kl., Denkschr., vol. 95, p. 235.

Truncatulina robertsoniana Brady, 1881, Quart. J. Micr. Soc., vol. 21, p. 65 .

Even if the two morphotypes may be easily distinguished by the smaller size, reduced number of chambers per whorl (7-9), and oblique intercameral sutures on the spiral side of Parrelloides bradyi, in agreement with Belanger and Berggren (1986) and van Morkhoven et al. (1986), we consider them as representing, respectively, the macrospheric and microspheric forms of the same species. Parrelloides bradyi Trauth, therefore, ought to be considered a junior synonym of Parrelloides robertsonianus (Brady). We refer these forms, following Beldford (1966) to Parrelloides, because of their radial wall structure as opposed to the granular wall of Cibicidoides.

These taxa are present, as common components of the bathyal benthic assemblage, only in the Neogene, pre-Pleistocene sediments of the Mediterranean basin, and are still living today in the Atlantic Ocean.

\section{Pullenia osloensis Feyling-Hanssen}

(Plate 3, Figs. 15-16)

Pullenia osloensis Feyling-Hanssen, 1954, Norsk Geol. Tidsskr., v. 33, no. 3-4, p. 194.

Slightly compressed, subspherical test, five chambers per whorl and slightly depressed sutures characterize this species and distinguish it from the more spherical, four-chambered Pullenia bulloides.

\section{Pyrgo depressa (d'Orbigny)}

Biloculina depressa d'Orbigny, 1826, Ann. Sci. Nat., ser. 1, vol. 7, p. 298, model no. 91.

The strongly depressed, subrounded test with acute periphery is characterized by its elongate, slit-like aperture, which distinguishes this species from Pyrgo murrhyna (Schwager) with a rounded aperture at the end of a non-protruding tube.

\section{Pyrgo lucernula (Schwager)}

Biloculina lucernula Schwager, 1886, Novara Exped., Geol. Theil, vol. 2, no. 2 , p. 202 , pl. 4 , figs. $14 a-c$.

The strongly protruding, tubular neck supporting its circular aperture is the characteristic feature of this inflated, circular to elongate species.

\section{Stilostomella antillea (Cushman)}

Nodosaria antillea Cushman, 1923, U. S. Nat. Mus. Bull., no. 104, p. 91 , pl. 14, fig. 9 .

This species, with an elongate, uniserial, rectilinear test, is distinguished from Stilostomella monilis (Silvestri) by its subovate, non-subspherical, chambers with longer, scattered, fine spines at the base.

\section{Uvigerina pygmaea d'Orbigny}

Uvigerina pygmaea d'Orbigny, 1826, Ann. Sci. Nat., ser. 1, vol. 7, p. 269.

Our specimens always exhibit blade-like costae in all the chambers, but in the last one or two chambers, the ornamentation is generally represented by fine, short spines evenly distributed on the surface.

\section{ACKNOWLEDGMENTS}

Thanks are due to K. A. Kastens, G. J. van der Zwaan, and to the unknown reviewer who greatly improved the original manuscript. This paper was financially supported by Italian National Research Council (CNR), grants CT 86.00649.05 and CT 87.00887.05.

\section{REFERENCES}

AGIP, 1957. Foraminiferi Padani (Terziario e Quaternario). Atlante iconografico e distribuzione stratigrafica. 52 plates. AGIP Mineraria SpA, Milano.

, 1982. Foraminifera Padani (Terziario e Quaternario). Atlante iconografico e distribuzione stratigrafica. II Ed. 52 plates. AGIP Mineraria SpA, Milano.
Aguirre, E., and Pasini, G., 1985. The Pliocene-Pleistocene Boundary. Episodes, 8:116-120.

Barbieri, F., 1967. The Foraminifera in the Pliocene section VernascaCastell'Arquato including the "Piacenzian Stratotype" (Piacenza Province). Mem. Soc. It. Sci. Nat., 15:145-163.

Belford, D. J., 1966. Miocene and Pliocene smaller foraminifera from Papua and New Guinea. Australia, Bur. Min. Res., Geol. Geophys., 79:1-306.

Bizon, G., and Bizon, J. J., 1984. Les foraminiferes des sediments profunds. In Bizon, J. J., and Burollet, P. F., (Eds.), Ecologie des microorganismes en Mediterranee occidentale (Ecomed), Paris, (Assn. Fr. Tech. Petrol.), 104-139.

Blanc-Vernet, L., 1969. Contribution a' l'etude des Foraminifers de Mediterranee. Recueil des Travaux de la Station Marine d'Endoume, 64:1-281.

Blanc-Vernet, L., Froget, C., and Sgarella, F., 1983. Paleoclimatologie d'une carotte de la Mer Tyrrhhenienne. Geol. Mediterran., 10:93104.

Boltovskoy, E., and Wright, R. C., 1976. Recent Foraminifera: The Hague, $515 \mathrm{p}$.

Brolsma, M. J., 1978. Quantitative foraminiferal analysis and environmental interpretation of the Pliocene and topmost Miocene on the south coast of Sicily. Utrecht Micropaleontol. Bull., 18:1-150.

Cita, M. B., 1975. The Miocene/Pliocene boundary: history and definition. In Saito, T. and Burckle, L. H. (Eds), Late Neogene Epoch Boundaries: Micropaleontology Press: 1-30.

Colalongo, M. L., and Sartoni, S., 1979. Schema Biostratigrafico per il Pliocene e il basso Pleistocene in Italia. In Nuovi contributi alla realizzazione della Carta Neotettonica d'Italia, 251:645-654.

Colalongo, M. L., Dondi, L., d'Onofrio, S., and Iaccarino, S., 1982. Schema biostratigrafico a Foraminiferi per il Pliocene e il basso Pleistocene nell'Appennino settentrionale e nella Pianura padana. In Cremonini, G., and Rici Lucchi, F. (Eds.), Guida alla geologia del margine appeninico-padano, 121-122.

Corliss, B.H., 1979. Taxonomy of Recent deep-sea benthonic foraminifera from the southeast Indian Ocean. Micropaleontology, 25:1-19.

De Amicis, D. A., 1985. I Foraminiferi del Pliocene inferiore di Bonfornello presso Termini Imerese, in Sicilia. Il Naturalista Siciliano, 145:1-63.

d'Onofrio, S., 1983. I Foraminiferi benthonici della sezione Vrica (Calabria, Italica). G. Geol., 43:327-364.

Douglass, R., and Woodruf, F., 1981. Deep sea benthic Foraminifera. In Emiliani, C. (Ed.), The Oceanic Lithosphere: The Sea, 7:12331327.

Fornasini, C., 1894. Contributo alla conoscenza della microfauna terziaria italian. Foraminiferi delle marne messinesi. Collezioni O. G. Costa e G. Seguenza (Museo di Napoli). Mem. R. Acc. Sc. Ist. Bologna, 4:1-32.

Katz, M. E., and Thunell, R. C., 1984. Benthic foraminiferal biofacies associated with middle Miocene to Early Pliocene oxygen-deficient conditions in the Eastern Mediterranean. J. Foram. Res., 14:187202.

Lohman, G. P., 1978. Abyssal benthonic foraminifera as hydrographic indicators in the western south Atlantic Ocean. J. Foram. Res., 8:134.

Margalef, R., 1958. Information theory in ecology. Foraminifera from bathyal depths in the eastern Mediterranean. Maritime Sediments, Spec. Publ., 1:251-262.

Parisi, E., Vignali, I., and Cita, M. B., 1982). Distribution of benthic foraminifers in deep water sediments from the southern Andriatic and Ionian basin. Ann. Geol. Pays Hell., 31:1-15.

Parker, F. L., 1958. Eastern Mediterranean Foraminifers. Repts. Swed. Deep-Sea Exped., 8:219-283.

Phleger, F. B., and Soutar, A., 1973. Production of benthic foraminifera in three east Pacific Oxygen minima. Micropaleontology, 19: 110-115.

Raffi, I., and Rio, D., 1979. Calcareous nannofossil biostratigraphy of DSDP Site 132-Leg 13 (Tyrrhenian Sea-Western Mediterranean). Riv. It. Paleontol. Strat., 85:127-172.

Raffi I., and Sprovieri, R., 1984. Calcareous plankton in the DSDP Hole 125-Leg 13 (Ionian Sea-Eastern Mediterranean): a review. Boll. Soc. Paleontol. It., 23:53-73.

Rio, D., 1982. The fossil distribution of Coccolithophore Genus Gephyrcapsa Kamptner and related Plio-Pleistocene chronostratigraphic 
problems. In Prell, W. L., Gardner, J. V., et al., Init. Repts. DSDP, 68: Washington (U.S. Govt. Printing Office), 325-343.

Rio, D., Backman, J., and Raffi, I., 1988. Calcareous nannofossil biochronology and the Pliocene/Pleistocene boundary. In van Couvering, J. (Ed.), The Neogene/Quaternary Boundary. Final Report, IGCP Project 41.

Rio, D., and Sprovieri, R., 1985. Biostratigrafia integrata del Plio-Pleistocene inferiore mediterraneo in un' ottica di Stratigrafia Sistemica. Boll. Soc. Paleontol. It., 2565-85.

Rio, D., Sprovieri, R., and Raffi, I., 1984. Calcareous plankton biostratigraphy and biochronology of the Pliocene-Lower Pleistocene succession of the Capo Rossello area, Sicily. Mar. Micropaleontol. 9:135-180.

Ruggieri, G., Buccheri, G., Greco, A., and Sprovieri, R., 1975. Un affioramento di Siciliano nel quadro della revisione della stratigrafia del Pleistocene inferiore. Boll. Soc. Geol. It., 94:889-914.

Ruggieri, G., Rio, D., and Sprovieri, R., 1984. Remarks on the chronostratigraphic classification of Lower Pleistocene. Boll. Soc. Geol. It., 103:251-259.

Ryan, W.B.F., Hsü, K.J., et al., 1973. Init. Repts. DSDP, 13, Washington (U.S. Govt. Printing Office).

Seguenza, G., 1880. Le formazioni terziarie della provincia de Reggio (Calabria). Mem. R. Acc. Lincei, 4:1-445.

Shackleton, N. J., Backmann, J., Zimmerman, H., Kent, D. V., Hall, M. A., Roberts, D. G., Schnitker, D., Baldauf, J. G., Despraires, A., Homrighausen, R., Huddlestun, P., Keene, J. B., Kaltemback, A. J., Krumsiek, K.A.O., Morton, A. C., Murray, J. W., and WestbergSmith. J., 1984. Oxygen isotope calibration of the onset of ice-rafting and history of glaciation in North Atlantic region. Nature, 307: 620-623.

Silvestri, A., 1899. Foraminiferi pliocenici della provincia di Siena. Mem. Pont. Acc. Nuovi Lincei, 15:156-381.

1904. Ricerche strutturali su alcune forme dei Trubi di Bonfornello (Palermo). Mem. Pont. Acc. Romana Nuovi Lincei, 22: 235-276.

Silvestri, O., 1872. Saggio di studi sulla fauna microscopica fossile appartenente al terreno subappennino italiano. Atti Acc. Gioenia, 2:1108.

Sprovieri, R., 1977. Distribuzione dei foraminiferi bentonici nel Trubi di Bonfornello (Palermo). Boll. Soc. Paleontol. It., 16:61-68.
1978. I foraminiferi benthonici della sezione plio-pleistocenica di Capo Rossello (Agrigento). Boll. Soc. Paleontol. It., 17:68-97. 1979. I foraminiferi benthonici del Pliocene inferiore lungo la costa nord-occidentale della Sicilia. Nat. Sic., 3:61-78.

1981. Uvigerina costato-caudata $\mathrm{n}$. sp., nuova specie per il limite plio-pleistocenico. Boll. Soc. Paleontol. It., 20:159-162.

1985. Paleotemperature changes and speciation among benthic foraminifera in the Mediterranean Pliocene. Boll. Soc. Paleontol. It., 24:13-21.

Sprovieri, R., and Barone, G., 1982. I Foraminiferi benthonici della sezione pliocenica di Punta Piccola (Agrigento, Sicilia). Geol. Rom., 21:677-686.

Sprovieri, R., Thunell, R., and Howell, M., 1986. Paleontological and geochemical analysis of three laminated sedimentary units of Late Pliocene-Early Pleistocene age from the Monte San Nicola section in Sicily. Riv. It. Paleontol. Strat., 92:401-434.

Streeter, S. S., and Shackleton, N. J., 1979. Paleocirculation of the deep North Atlantic: 150,000-yr. record of benthic foraminifera and Oxygen-18. Science, 203:168-171.

Todd, R., 1958. Foraminifera from western Mediterranean deep-sea cores. Repts. Swed. Deep-Sea Exped., 3:169-215.

van der Zwaan, G. J., 1982. Paleoecology of Late Miocene Mediterranean foraminifera. Utrecht Micropaleontol. Bull., 25:1-202. 1983. Quantitative analyses and the reconstruction of benthic foraminiferal communities. Utrecht Micropaleontol. Bull., 30: 49-69.

van Morkhoven, F.P.C.M., Berggren, W. A., and Edwards, A. S., 1986. Cenozoic cosmopolitan deep-water benthic foraminifera. Bull. Centre Rech. Explor.-Prod. Elf-Aquitaine, Mem 11.

Wright, R., 1978a. Neogene paleobathymetry of the Mediterranean based on benthonic Foraminifera from DSDP Leg 42A. In Hsü, K. J., Montadert, L., et al., Init. Repts. DSDP, 42: Washington (U.S. Govt. Printing Office), 837-846. 1978b. Neogene benthic Foraminifers from DSDP Leg 42A, Mediterranean Sea. In Hsü, K. J., Montadert, L., et al., Init. Repts. DSDP, 42: Washington (U.S. Govt. Printing Office), 709-726.

Date of initial receipt: 1 December 1987

Date of acceptance: 8 March 1989

Ms 107B-149 


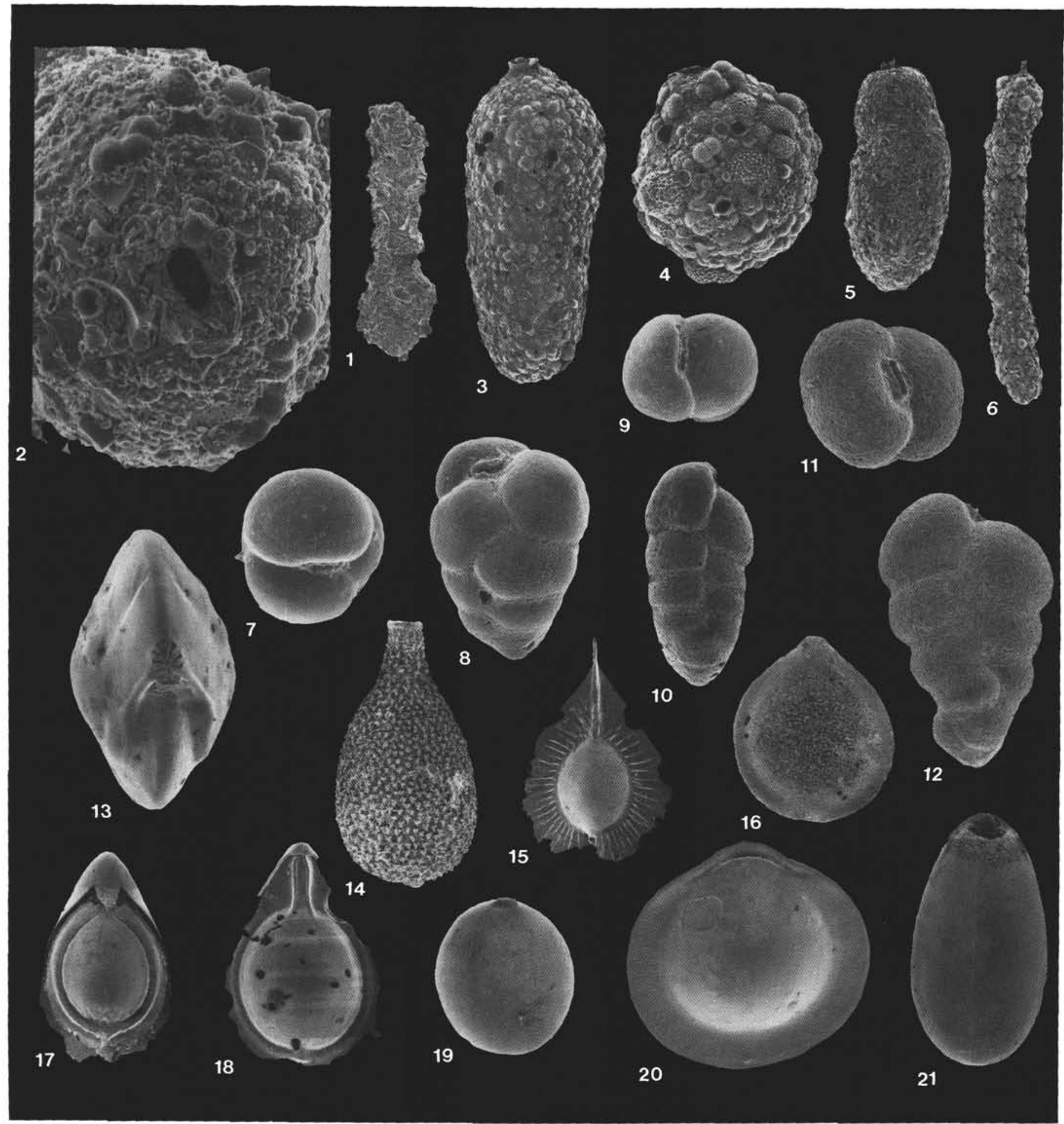

Plate 1. 1, 2. Bigenerina nodosaria d'Orbigny. 1. Sample 107-653A-18X-4, 105-107 cm (47X). 2. Sample 107-653A-21X-5, 105-107 cm (apertural view, magnified, 299X). 3, 4. Cylindroclavulina rudis (Costa). Sample 107-654A-17R-3, 111-113 cm (3, 30X; 4, apertural view of a young specimen, 67X). 5. Martinottiella communis (d'Orbigny). Sample 107-654A-20R-2, 115-117 cm (48X). 6. Martinottiella perparva (Cushman). Sample 107653A-18X-2, 45-47 cm (48X). 7, 8. Eggerella bradyi Cushman. Sample 107-653A-8H-2, 105-107 cm (97X). 9, 10. Karreriella bradyi (Cushman). 9. Sample 107-653A-11H-3, 114-116 cm (64X). 10. Sample 107-653A-13H-5, 105-107 cm (68X). 11, 12. Karreriella novangliae (Cushman). Sample 107-653A-5H-6, 105-107 cm (64X). 13. Cribrorobulina serpens clericii (Fornasini). Sample 107-654A-15R-6, 116-118 cm (apertural view, 67X). 14. Lagena gibbera Buchner. Sample 107-652A-7R-1, 129-134 cm (100X). 15. Fissurina radiata Seguenza. Sample 107-653A-2H-1, 45-47 cm (64X). 16. Fissurina marginata (Montagu). Sample 107-653A-22X-2, 45-47 cm (99X). 17. Fissurina cucullata Silvestri. Sample 107-653A-9H-6, 45-47 cm (66X). 18. Fissurina longirostris Seguenza. Sample 107-652A-13R-3, 143-146 cm (66X). 19. Parafissurina abnormis Parr. Sample 107-653A-8H-4, $45-47 \mathrm{~cm}$ (135X). 20. Parafissurina basicarinata Parr. Sample 107-652A-8R-2, 80-83 cm (134X). 21. Parafissurina lateralis (Cushman). Sample 107-653A-9H-6, 45-47 cm (99X). 


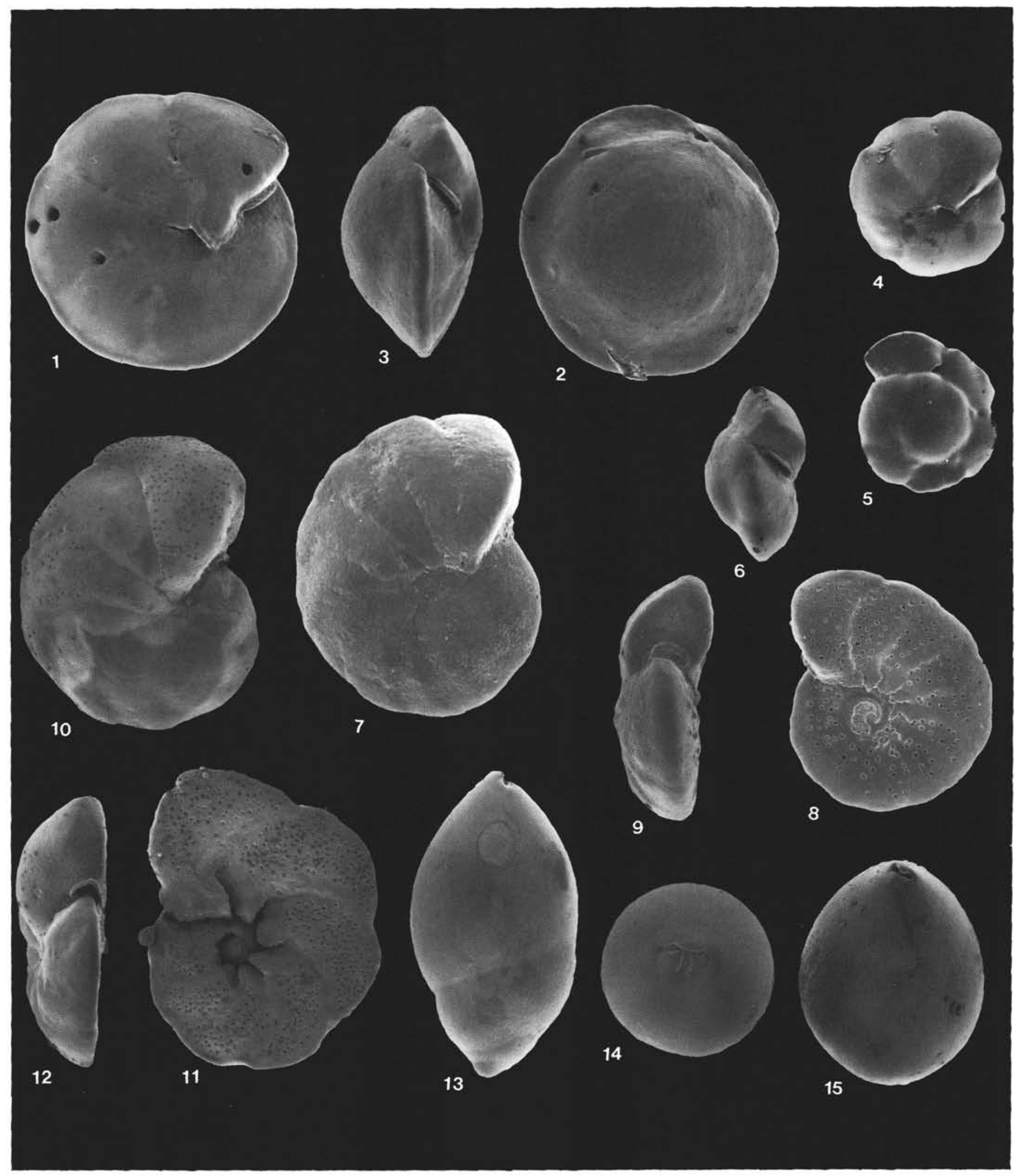

Plate 2. 1-3. Oridorsalis stellatus (Silvestri). 1. Sample 107-653A-13H-5, 105-107 cm (99X). 2, 3. Sample 107-653A-14X-6, 105-107 cm (99X). 46. Oridorsalis umbonatus (Reuss). Sample 107-652A-4R-5, 84-86 cm (134X). 7-9. Anomalinoides helicinus (Costa). 7. Sample 107-653A-23X-1, 45-47 cm (97X). 8. Sample 107-653A-20X-1, 45-47 cm (97X). 9. Sample 107-654A-24R-1, 116-118 cm (96X). 10-12. Hanzawaia rhodiensis (Terquem). Sample 107-653A-9H-4, 110-112 cm (132X). 13, 14. Ellipsopolymorphina fornasinii Galloway. Sample 107-653A-20X-2, 45-47 cm. 13, $95 \mathrm{X} ; 14,97 \mathrm{X})$. 15. Ellipsoidina ellipsoides Seguenza. Sample 107-652A-15R-4, 70-74 cm (68X). 

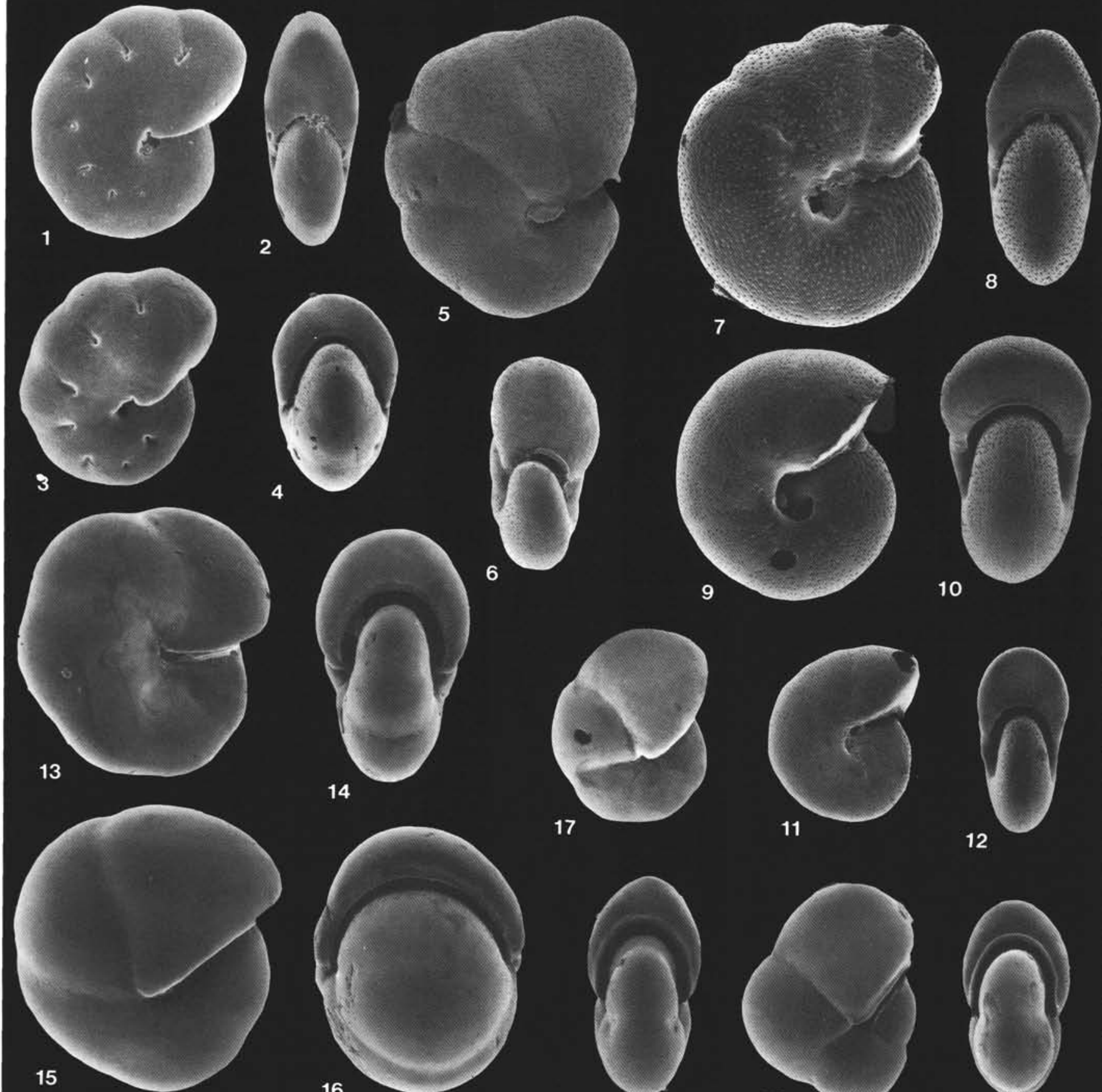

14
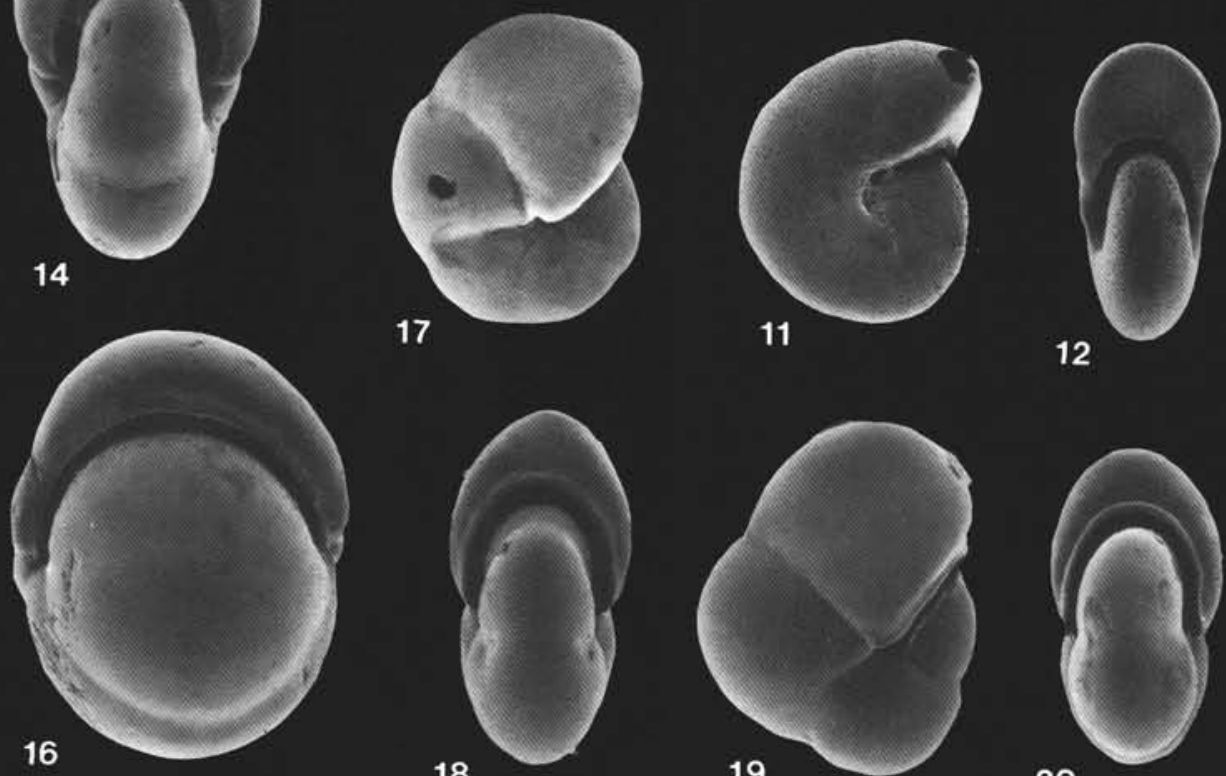

18
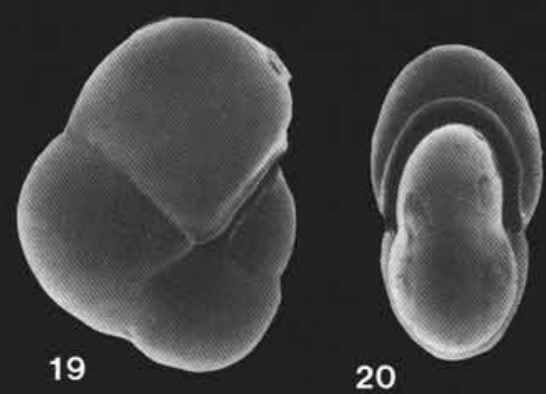

Plate 3. 1, 2. Astrononion stelligerum (d'Orbigny). Sample 107-653A-18X-2, $45-47 \mathrm{~cm}(1,132 \mathrm{X} ; 2,134 \mathrm{X})$. 3, 4. Astrononion italicum Cushman and Edwards. Sample 107-653A-16X-5, 105-107 cm (136X). 5, 6. Nonionella cf. sloani (d'Orbigny). Sample 107-652A-19R-6, 105-107 cm (134X). 7, 8. Melonis barleeanus (Williamson). 7. Sample 107-654A-20R-3, 115-117 cm (99X). 8. Sample 107-654A-16R-4, 116-118 cm (99X). 9, 10. Melonis pompilioides (Fichtel and Moll). Sample 654A-14R-2, 116-118 cm (99X). 11, 12. Melonis affinis (Reuss). Sample 107-653A-12X-5, 105-107 cm (11, 99X; 12, 10OX). 13, 14. Pullenia salisburyi Stewart and Stewart. 13. Sample 107-653A-12H-5, 105-107 cm (135X). 14. Sample 107-652A-16R-1, 38-42 cm (136X). 15, 16. Pullenia osloensis Feyling-Hanssen. Sample 107-653A-5H-6, 105-107 cm (135X). 17, 18. Pullenia quinqueloba (Reuss). Sample 107-653A-12H-2, 105-107 cm (17, 132X;18, 135X). 19, 20. Pullenia quadriloba (Reuss). Sample 107-652A-12R-2, $116-120 \mathrm{~cm}$ (132X). 

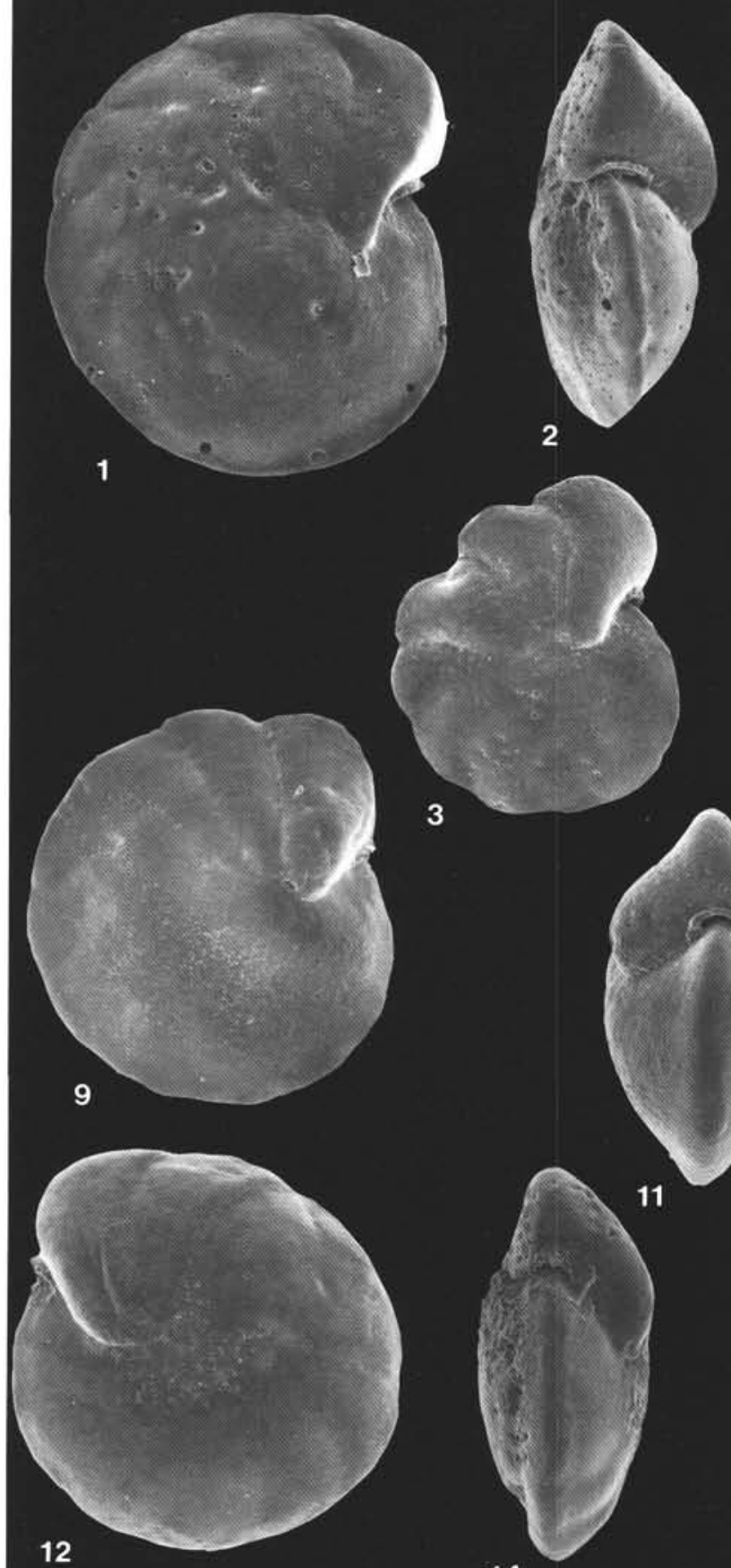

12

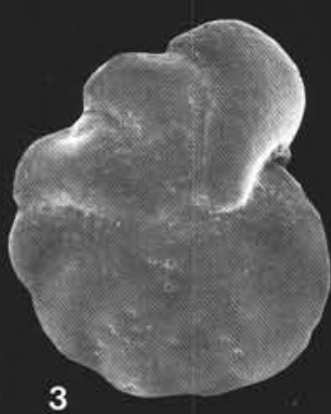

3

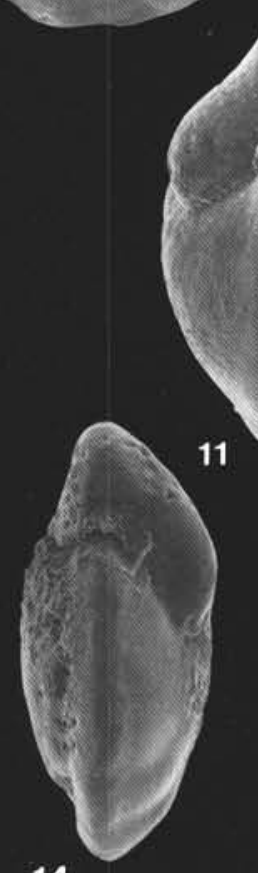

14
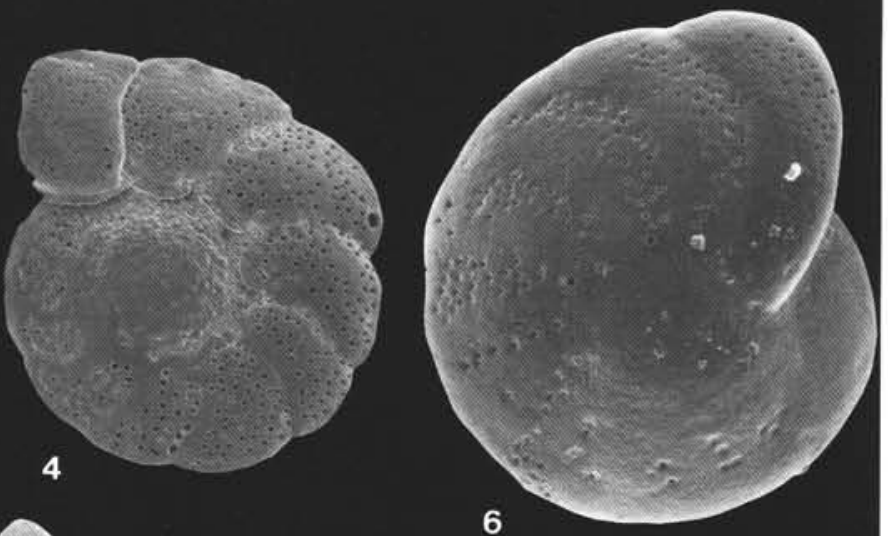

5
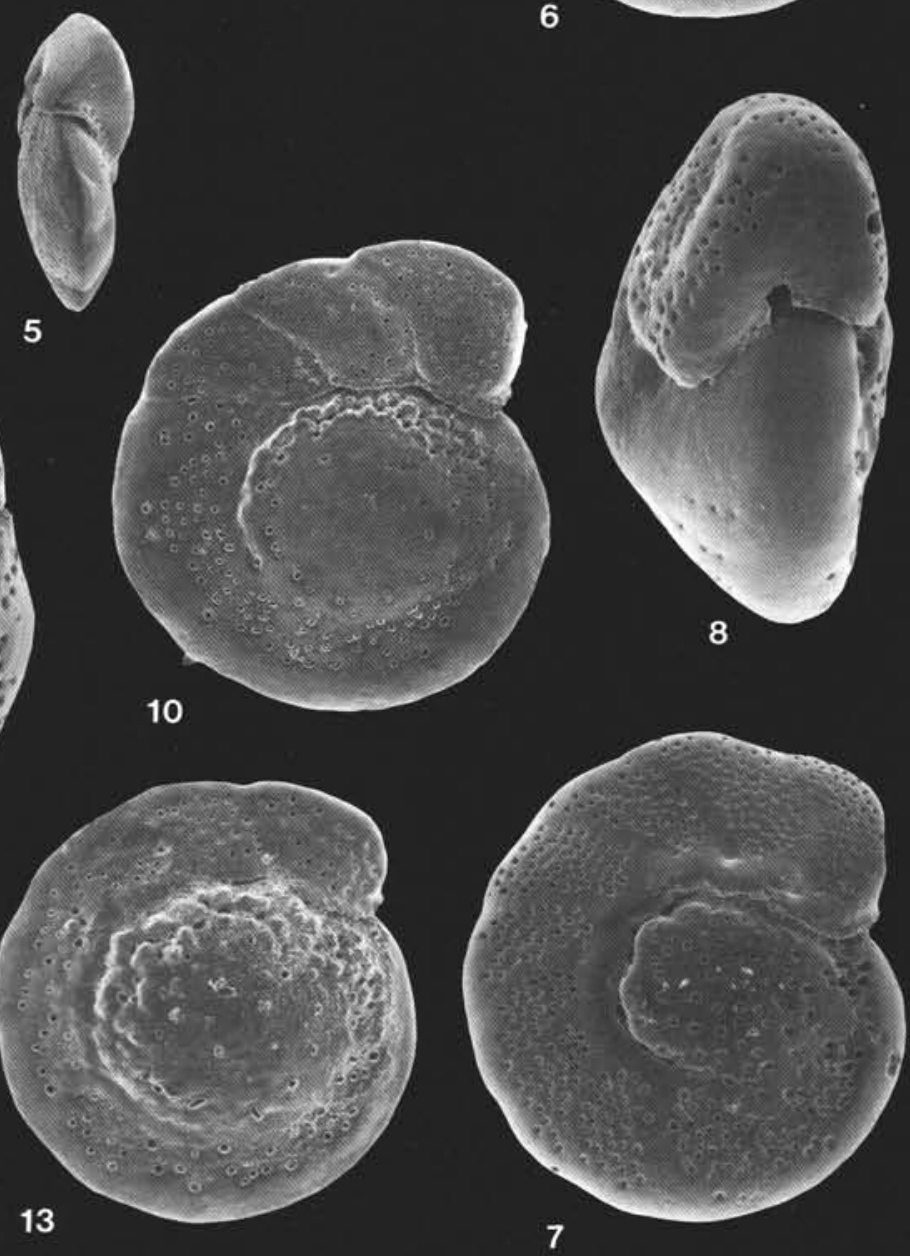

Plate 4. 1, 2. Cibicidoides agrigentinus. Sample 107-654A-15R-3, 116-118 cm (98X). 3-5. Cibicidoides ungerianus (d'Orbigny). 3. Sample 107653A-21X-4, 105-107 cm (66X). 4. Sample 107-654A-21R-5, 116-118 cm (66X). 5. Sample 107-654A-24R-2, 116-118 cm (66X). 6-8. Cibicidoides ornatus (Costa). 6. Sample 107-654A-15R-2, 116-118 cm (66X). 7. Sample 107-654A-17R-4, 110-112 cm (66X). 8. Sample 107-654A-15R-1, 45-47 cm (66X). 9-11. Cibicidoides pachyderma (Rzehak). Sample 107-653A-lH-2, 105-107 cm (66X). 12-14. Cibicidoides kullenbergi (Parker). Sample $107-653 \mathrm{~A}-10 \mathrm{H}-1,45-47 \mathrm{~cm}(12$ and $13,67 \mathrm{X} ; 14,66 \mathrm{X})$. 


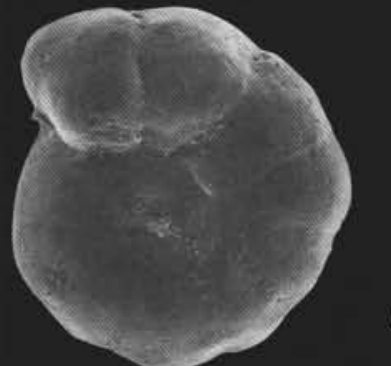

1
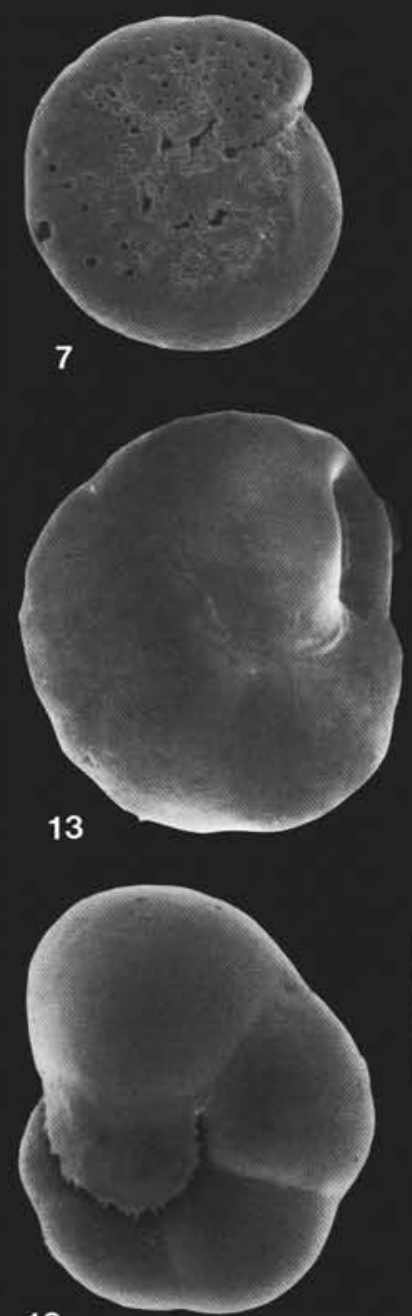

19
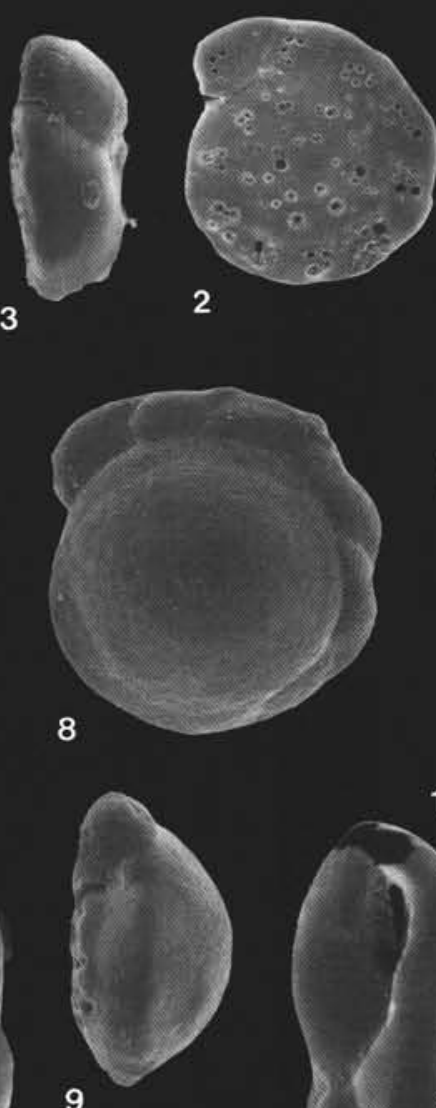

9
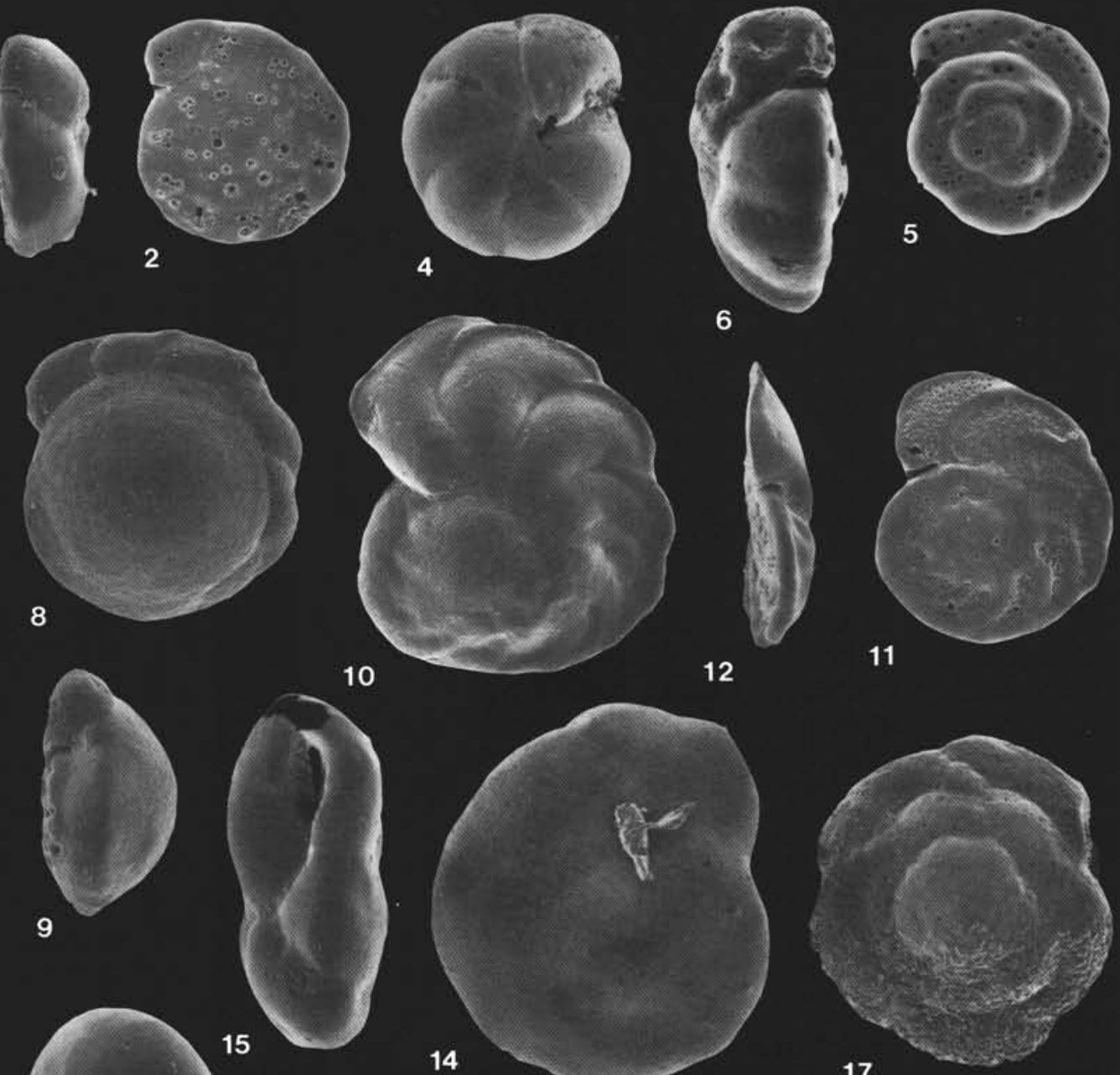

6

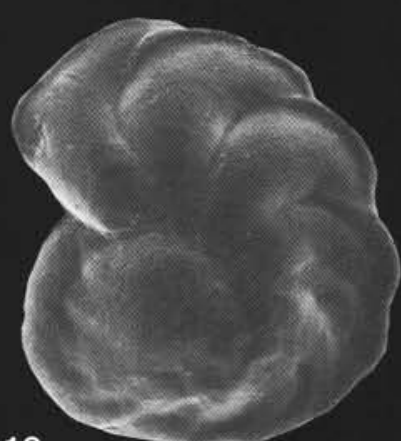

12

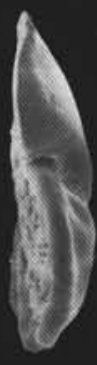

11

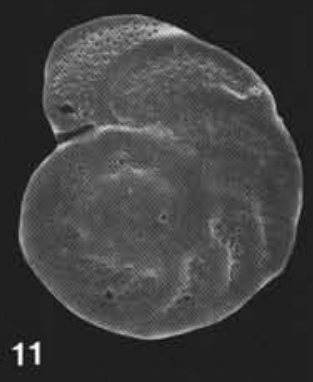

14

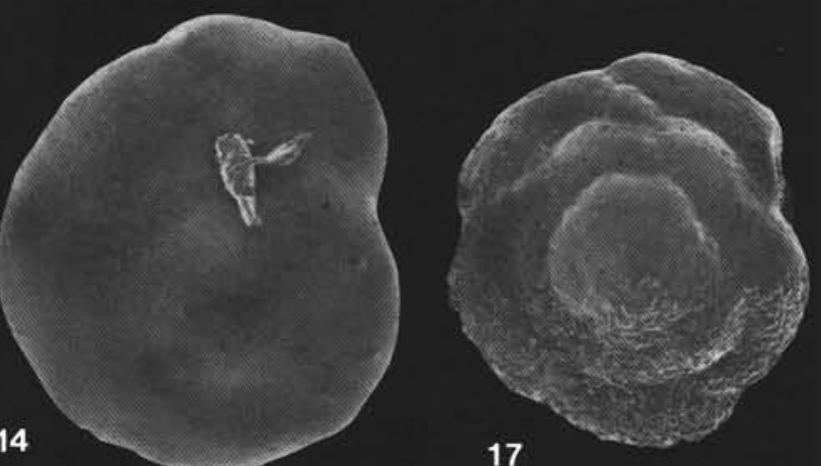

17
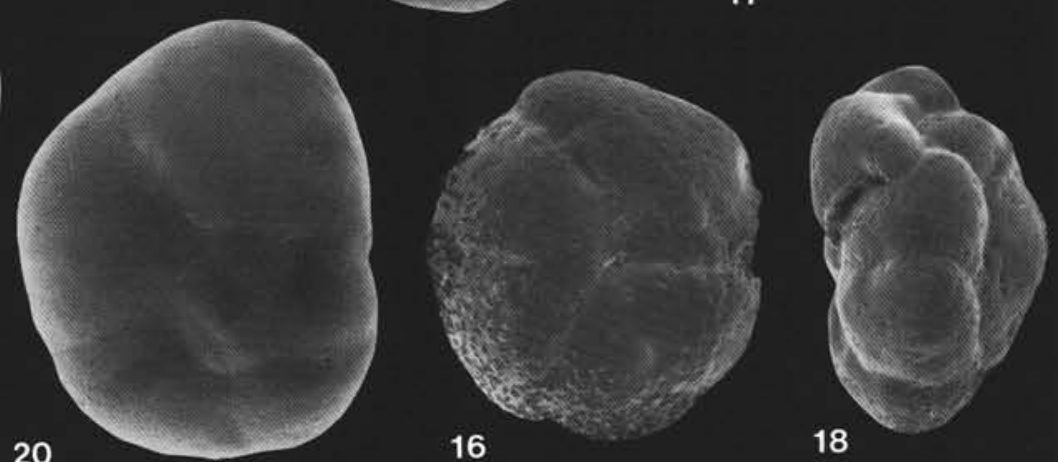

Plate 5. 1-3. Parrelloides robertsonianus (Brady). 1. Sample 107-653A-12H-5, 105-107 cm (65X). 2, 3. Sample 107-654A-21R-3, 116-118 cm (65X). 4-6. Parrelloides bradyi (Trauth). Sample 107-652A-15R-1, 9-11 cm (134X). 7-9. Cibicidoides(?) italicus (di Napoli). Sample 107-653A-18X-4, 105$107 \mathrm{~cm} .(7,67 \mathrm{X} ; 8,66 \mathrm{X} ; 9,95 \mathrm{X}) .10-12$. Cibicides wuellerstorfi (Schwager). 10, 11. Sample 107-654A-14R-2, 116-118 cm (66X). 12. Sample 107653A-14X-1, 105-107 cm (66X). 13-15. Pseudoparrella exigua bathyalis (Conato). Sample 107-654A-12R-2, 116-118 cm (13, 197X; 14, 207X; 15, 198X). 16-18. Eponides pusillus Parr. Sample 107-653A-5H-3, 105-107 cm (16, 197X; 17, 200X; 18, 199X). 19-21. Quadrimorphina laevigata (Phleger and Parker). Sample 107-652A-19R-6, 105-107 cm (19 and 20, 207X; 21, 205X). 